\title{
Advancements in three-dimensional titanium alloy mesh scaffolds fabricated by electron beam melting for biomedical devices: mechanical and biological aspects
}

\author{
Krishna Chaitanya Nune ${ }^{1}$, Shujun $\mathrm{Li}^{2}$ and R. Devesh Kumar Misra ${ }^{{ }^{*}}$
}

\begin{abstract}
We elucidate here the process-structure-property relationships in three-dimensional (3D) implantable titanium alloy biomaterials processed by electron beam melting (EBM) that is based on the principle of additive manufacturing. The conventional methods for processing of biomedical devices including freeze casting and sintering are limited because of the difficulties in adaptation at the host site and difference in the micro/macrostructure, mechanical, and physical properties with the host tissue. In this regard, EBM has a unique advantage of processing patient-specific complex designs, which can be either obtained from the computed tomography (CT) scan of the defect site or through a computeraided design (CAD) program. This review introduces and summarizes the evolution and underlying reasons that have motivated 3D printing of scaffolds for tissue regeneration. The overview comprises of two parts for obtaining ultimate functionalities. The first part focuses on obtaining the ultimate functionalities in terms of mechanical properties of 3D titanium alloy scaffolds fabricated by EBM with different characteristics based on design, unit cell, processing parameters, scan speed, porosity, and heat treatment. The second part focuses on the advancement of enhancing biological responses of these $3 \mathrm{D}$ scaffolds and the influence of surface modification on cell-material interactions. The overview concludes with a discussion on the clinical trials of these 3D porous scaffolds illustrating their potential in meeting the current needs of the biomedical industry.
\end{abstract}

Keywords: Electron beam melting, 3D printing, tissue engineering, mechanical properties, biocompatibility

\section{INTRODUCTION}

Evolution of additive manufacturing

Additive manufacturing is a rapid prototype (RP) technique involving layer-by-layer processing of three-dimensional (3D) complex structures as directed by the computer-aided design (CAD) [1,2]. Additive manufacturing can be utilized to fabricate complex structures of relevance to aerospace and patient-specific implants. For instance, biomedical devices can be fabricated using the CAD program or computed tomography (CT) scan of a damaged site that provides a $3 \mathrm{D}$ visualization of the damaged or defect region. The CT scan data is subsequently transformed into a 3D design using a commercial software (MIMICS), which generates a STL (STereoLithography) file. Next this file is fed as an input file to the $3 \mathrm{D}$ printing system, to print the scaffold or component.

The fabrication of porous materials has been explored since 1940s, when pores were introduced in aluminum through the addition of mercury to the melt [3]. However, the idea of introducing porous materials in the biomedical industry started only in 1970s with the aim to enhance osseointegration and enable bone ingrowth to potentially replace conventional solid/dense implants with porous coatings [4]. In this regard, several engineering materials such as metals, ceramics, polymers, and composites were rendered porous through the adaptation of advanced manufacturing approaches [516]. In load-bearing orthopedic applications, irrespective

${ }^{1}$ Biomaterials Science and Engineering Laboratory Metallurgical, Materials and Biomedical Engineering Department, University of Texas at El Paso, TX 79968, USA

${ }^{2}$ Institute of Metals Research, Chinese Academy of Sciences, Shenyang 11016, China

*Corresponding author (email: dmisra2@utep.edu) 
of the manufacturing technique, brittle behavior of ceramics and poor strength of polymers limit their applications for bone implants. Thus, titanium, cobaltchromium, stainless steel, tantalum, and magnesium alloys are considered worthy of research.

Titanium and its alloys have been widely used for several decades as monolithic and solid implants. They have inherent advantages of specific strength, low stiffness, good corrosion and fatigue resistance in physiological medium and have been extensively used for dental, orthopedic, and maxillofacial applications $[17,18]$. Titanium alloy has superior biological and mechanical properties, in comparison to other metals, because of the favorable microstructure and stable passive film. 3D printing of porous structures of titanium alloys have the ability to reduce modulus mismatch in the context of biomedical devices [3,19-21]. Thermo-mechanically processed solid titanium alloys have higher elastic modulus ( $\sim 90-115 \mathrm{GPa})$ compared to the surrounding tissue (cortical hard bone: 15-25 GPa; cancellous or trabecular soft bone with open cellular structure: $\sim 0.1-4.5 \mathrm{GPa}$ ) [2224]. This leads to stress-shielding, because of which the implant takes the maximum load [25]. An important consequence of biomechanical mismatch is the possibility of reduced rate of bone healing [25]. Hence, a viable approach to alleviate biomechanical mismatch is to fabricate open cellular porous structures that are characterized by significantly reduced modulus and reduced density. Another approach is alloy design. In the last decade, with the advancement in manufacturing techniques, porous metal structures have been fabricated by additive manufacturing (AM) (layer-by-layer fabrication) from precursor powders using electron beam melting (EBM) and selective laser melting (SLM) [26-28]. The following sections summarize the advancements in design, structure, process, and properties of porous titanium alloy components fabricated by EBM for orthopedic applications.

\section{Design considerations}

In additive manufacturing, the properties of the fabricated component are governed by the unit cell, while the design is dictated by the resolution offered by the additive manufacturing process/equipment [1]. For ARCAM A1 the resolution is $\pm 0.4 \mathrm{~mm}$ based on the information in the user's manual. Irrespective of the above, compressive strength, endurance and elastic modulus can be optimized to ensure the long term success of the implant [1,29-32]. Vascularization is another aspect that merits consideration during design, because vascularization promotes diffusion of nutrients that is necessary for cell proliferation and differentiation. Biomedical devices of different alloys including titanium alloys, stainless steel and cobalt-chromium alloys have been actively considered for 3D printing [1].

The aspects that are of significance in the design and processing of optimal architecture for bone tissue engineering applications include: (a) high porosity-high strength combination with elastic modulus similar to bone, (b) interconnected porous structure with clinically relevant geometry that allows oxygen and exchange of nutrients, and facilitates efficient cell seeding and production of extracellular matrix (ECM), and (c) appropriate chemistry and topography for cell attachment, proliferation, and differentiation [33,34].

With regard to regeneration of an injured tissue, mimicking cellular and physiological environment, involving neighboring cells, extracellular matrix, flow of physiological fluid, mechanical, chemical and topographical cues is a primary requirement $[1,35,36]$. Considering that the response of cells depends on the available environment, the ECM needs to be considered as part of the environment to ensure cell-material interaction and to provide a route for sensing chemical and physical cues [1,37-39]. Hence, tissue engineered scaffolds are expected to play a determining role in ECM modeling and governing cell-material interaction during the regeneration process. In this regard, scaffolds are required to be non-toxic and biocompatible $[1,40,41]$. They are also expected to provide structural support to cells during tissue regeneration/remodeling $[1,42,43]$. The scaffold with desired physical and chemical properties dictates tissue engineering. For example, the elastic modulus of ECM dictates differentiation of cells into different lineage. High stiffness is important for bone forming cells $[1,44,45]$. In the case of cardiac muscle cells, the geometry of scaffold is an important issue in aligning cells, which may enable directional contraction of tissue from the perspective of efficient blood transfer $[1,46]$.

In regard to bone tissue regeneration, pore size and percentage of porosity impact osteogenesis [18]. In the case of bio-inert materials, porosity and pore size generally do not affect osteogenesis, but with regard to bioactive materials, porosity and pore size significantly influence osteogenesis [47-49]. It is pertinent to keep in mind that porosity is not the cause for hypoxia, which is considered responsible for encouraging osteochondral ossification [1,50]. During design, degree of porosity and pore size are important considerations from the per- 
spective of long term structural support. Vascularization availability of micro-vessels is required for the transport of oxygen and nutrients, otherwise cells may die $[1,51]$. Thus, ensuring desired growth of new blood vessels and adequate space for growth is a necessity $[1,51]$.

An important area of application of additive manufacturing relates to the design of scaffolds to perform a particular function. For example, electroactive scaffolds with directional porosity enabled alignment of nerve cells and acted as a guiding cue for growth [52]. Electrical stimulation also promoted nerve growth factor (NGF) [53]. Scaffolds play a determining role in transmitting the applied external stimuli to the cells and enabling the biological functions to be controlled $[1,54,55]$. Repair of the annulus fibrous rupture was accomplished by loading the scaffolds with mesenchymal stem cells, eliminating herniation of nucleus pulposus tissue and stabilization of disk height $[1,56]$.

In summary, tissue-specific scaffolds are preferred because the complex structure can be mimicked and the damaged tissue can be restored. Moreover, 3D scaffold with interconnected porous structure provides space for vascularization, and serves as a template for the regeneration of tissue. Also, the porous structure can be designed to suit a particular tissue-specific environment, e.g., directionality for nerve regeneration. The aforementioned requirements can be conveniently met by designing 3D scaffolds, which is not feasible using conventional approaches.

\section{D ADDITIVE MANUFACTURING METHODS FOR BONE TISSUE ENGINEERING}

Prior to the development of 3D additive manufacturing methods, the methods adopted to fabricate 3D porous scaffolds include freeze drying, solvent casting with particulate leaching, fiber bonding, membrane lamination, and gas foaming [16,57-59]. In these methods, it is difficult to control the pore size, shape, and pore interconnectivity [60]. These challenges can now be met via rapid prototyping or $3 \mathrm{D}$ printing, as described in the following section below. Patient specific scaffolds or devices with tailored dimensions and porosity can be conveniently processed by the additive manufacturing method.

\section{Electron beam melting}

An EBM system (Fig. 1) to process 3D porous scaffolds has an electron column, where a focused electron beam is produced and scans a uniformly raked layer of powder, which is gravity fed from the feed stock $[1,61]$. The ARCAM A1 system, using a DC current of $\sim 10 \mathrm{~mA}$ and anode potential of $60 \mathrm{kV}$ drives a tungsten filament in a $3 \mathrm{~kW}$ electron gun. A combination of electromagnetic lenses focuses the electron beam (beam spotsize (FWHM) $0.2-1.0 \mathrm{~mm}$ ). The system operates in vacuum of < $10^{4}$ Torr. The resolution is $\pm 0.025 \mathrm{~mm}$ [ARCAM user's manual]. The selective melting of powder is based on CAD design. The powder bed is initially heated to $\sim 750^{\circ} \mathrm{C}$, for instance, in the case of titanium alloy powder $[1,27,62-64]$. In general, powders are heated to $0.5-0.6 T_{\mathrm{m}}$ ( $T_{\mathrm{m}}$ : melting temperature of powder). Packing, powder size, beam energy, powder conductivity and heat of fusion are important contributors. The selective melting of powder that is added in the build direction produces a complex 3D structure. Also, presented in Fig. 1 is an SLM system, also referred as selective laser sintering (SLS) (Fig. 1), which is a conventional particle-bonding system, using a laser beam (e.g., $\mathrm{CO}_{2}$ laser) in lieu of electron beam [61].

Illustrations of biomedical devices produced via additive manufacturing are presented in Fig. 2 [62]. Near net-shape components can be produced by additive manufacturing with little or no machining. Titanium alloy components processed by EBM were characterized by a columnar structure and $\sim 50-60 \mathrm{~nm}$ thick lamellar plates with indentation hardness of $\sim 2.5 \mathrm{GPa}$, which was similar to the hardness of $\sim 2.3 \mathrm{GPa}$ obtained for SLM processed component. Co-Cr alloy (Co-26Cr-6Mo-0.2C) was processed by EBM to fabricate femoral (knee) prototypes as a reticulated mesh structure (density of $1.5 \mathrm{~g} \mathrm{~cm}^{-3}$ ) [1,64] characterized by array of orthogonal $\mathrm{Cr}_{23} \mathrm{C}_{6}$ carbides. The microstructure of the $\mathrm{Co}-\mathrm{Cr}$ alloy was $\sim 2 \mu \mathrm{m}$ in the build plane, perpendicular to the build direction, and the carbide columns were present in the vertical plane, parallel to the build direction. The resulting structure had indentation hardness of $4.4 \mathrm{GPa}$, yield strength of $\sim 0.51 \mathrm{GPa}$ and tensile strength of $\sim 1.45 \mathrm{GPa}$ $[1,65]$. The fabricated knee exhibited a hardness of $5.9 \mathrm{GPa}$, while the prototype knee in the annealed condition had a lower hardness of $4.7 \mathrm{GPa}[1,65]$. The reticulated mesh strut structure had a high density of carbide arrays with indentation hardness of $6.2 \mathrm{GPa}$. The success achieved in obtaining a complex monolith and a reticulated mesh structure of Co-Cr alloy by EBM, that exhibited high strength, led to the conclusion that complex monoliths with multifunctional characteristics can be processed by EBM. The properties of titanium alloy fabricated by EBM and SLM are presented in Table 1 [65]. 

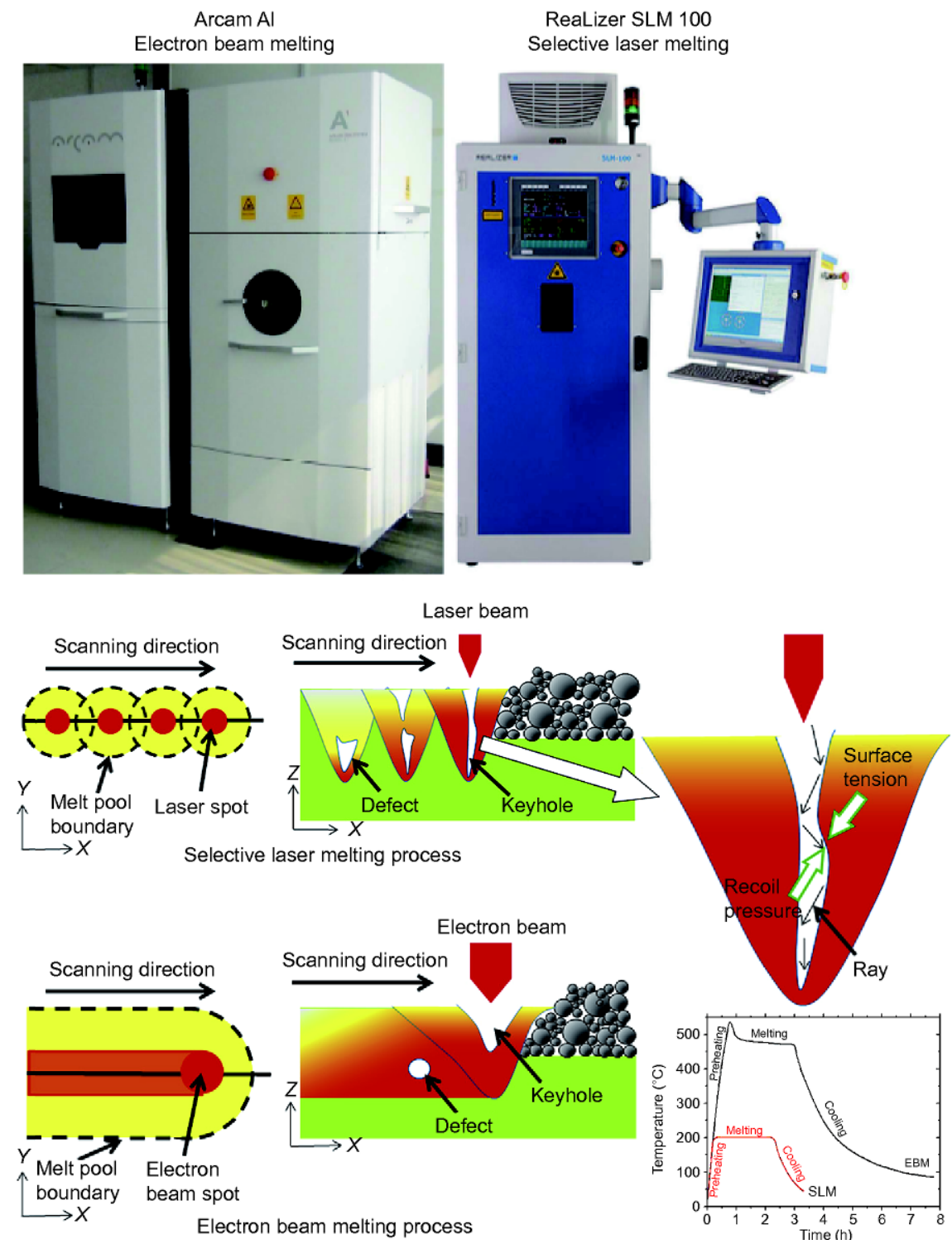

Figure 1 Commercially available EBM and SLM equipments along with the schematic representation of temperature variation of melting process for the substrate plate. Adapted from ref. [61], Copyright 2016, Elsevier.

\section{EBM: OBTAINING ULTIMATE FUNCTIONALITIES IN 3D TITANIUM ALLOY SCAFFOLDS}

\section{Part I: Mechanical properties}

It is important to obtain desired mechanical properties during fabrication of $3 \mathrm{D}$ scaffolds. This is essential for structural integrity, till such time new tissue is regenerated [66]. The mechanical properties depend on the specific anatomical location of application, i.e., soft or hard tissue $[67,68]$. The compressive strength of human bone is in the range of $\sim 2-12 \mathrm{MPa}$ for cancellous bone and $\sim 100-230 \mathrm{MPa}$ for cortical bone. The elastic modulus of cortical bone, cancellous bone and titanium alloy scaffold are $\sim 15-25 \mathrm{GPa}, \sim 0.1-4.5 \mathrm{GPa}$ and $\sim 110 \mathrm{GPa}$, respectively [69]. Scaffolds of strength less than the bone are additionally supported by plates, screws, or nails. The mismatch of elastic moduli between the scaffold and bone with a higher elastic modulus than host tissue leads to stress shielding and consequent bone resorption. In a recent study focused on understanding the mechanical property-porosity relationship (pore size $\sim 350-1000 \mu \mathrm{m}$ ) led to reduced elastic modulus of the porous implant, and minimized stress shielding, in vivo $[1,70]$. However, the 

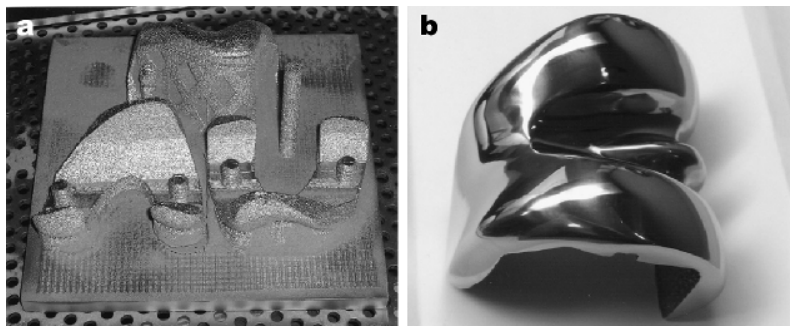

Figure 2 (a) Typical knee replacement component fabricated by EBM method and (b) finished part. Adapted from ref. [62], Copyright 2009, Elsevier.

scaffolds can rupture and give away if their strength is less than the host bone for load-bearing situations. It is desired that the scaffolds exhibit mechanical properties (elastic modulus and strength) similar to bone [1,71]. Ideally, it is preferred that a scaffold which substitutes for the bone, is modeled as a structure with multiple layers so that the mechanical properties vary across the structure. This can be made possible by having a gradient or graded structure with different porosity across the scaffold, which provides a means to vary the stiffness [72]. It is important to keep in mind that the mechanical strength depends on apparent density of the scaffold, where the thickness zone of inter-pore walls and pore size to beam thickness ratio dictates the mechanical strength of $3 \mathrm{D}$ printed porous scaffolds [73,74].

In general, the mechanical properties of $3 \mathrm{D}$ printed scaffolds depend on unit cell, pore architecture, pore volume, and percentage porosity. To ensure long term endurance and the ability to withstand impact, it is necessary that the fabricated materials have a good combination of strength and energy absorption capability, as discussed below. It is recognized that scaffolds with high interconnected porosity, though, preferred for tissue regeneration, but they may lack adequate mechanical strength and energy absorption capability. The mutually opposing requirement of high porosity and mechanical strength in conjunction with high energy absorption is a challenge.

\section{Role of unit cell design}

Recently, the effect of cell shape on mechanical properties and deformation mechanism was studied in EBM fabricated $\mathrm{Ti}-6 \mathrm{Al}-4 \mathrm{~V}$ reticulated mesh structure with different unit cell elements (cubic, G7, rhombic dodecahedron) [75]. These different unit cells provide a means to effectively balance the strength, elastic modulus and degradation behavior in cellular solids. It was observed that in the case of cellular structures with different unit cell, the underlying fatigue mechanism involved interaction of cyclic ratcheting and fatigue crack growth on the struts. This was closely related to coupling of buckling and bending deformation of the strut. On increasing the buckling deformation on the struts via design of cell shape, the cyclic ratcheting rate of the meshes during cyclic deformation was decreased and the compressive fatigue strength was increased. While increasing the bending deformation of the struts, the contribution of fatigue crack growth in the struts led to significant fatigue damage of mesh [75]. Moreover, the presence of rough surface and pores contained in the struts significantly deteriorated the compressive fatigue strength of the struts. It was also observed that by altering the influence of bending deformation, the stress-strain behavior transformed from brittle to ductile. It was demonstrated that Ti-6Al-4V cellular materials with high strength, low modulus, and desirable mechanical deformation behavior can be processed by EBM, involving tuning of cell design (Fig. 3) [75]. Table 2 summaries the properties of titanium alloy fabricated with different unit cell design by EBM [75].

\section{Role of porosity}

A comparative study of Ti-6Al-4V and Ti2448 alloy on the effect of porosity on mechanical properties indicated that both the compressive strength and yield strength decreased with increased porosity for both the alloys [76]. It was observed that $\mathrm{Ti}-6 \mathrm{Al}-4 \mathrm{~V}$ alloy with identical porosity (75\%) built using the same unit cell shape exhibited higher compressive strength and Young's modulus of

Table 1 List of mechanical properties of Ti-6Al-4V titanium alloy bars fabricated by additive manufacturing methods: EBM and SLM [65] (YS: yield strength; UTS: ultimate tensile strength)

\begin{tabular}{|c|c|c|c|c|c|c|c|c|c|c|c|c|}
\hline & \multicolumn{12}{|c|}{ Fabrication process } \\
\hline & \multicolumn{6}{|c|}{ EBM } & \multicolumn{6}{|c|}{ SLM } \\
\hline & \multicolumn{3}{|c|}{ Vertical } & \multicolumn{3}{|c|}{ Horizontal } & \multicolumn{3}{|c|}{ Vertical } & \multicolumn{3}{|c|}{ Horizontal } \\
\hline & $\Phi 7$ & $\Phi 4$ & $\Phi 1.2$ & $\Phi 7$ & $\Phi 4$ & $\Phi 1.2$ & $\Phi 7$ & $\Phi 4$ & $\Phi 1.2$ & $\Phi 7$ & $\Phi 4$ & $\Phi 1.2$ \\
\hline UTS (MPa) & 1033 & 1049 & 1177 & 982 & 1023 & 1168 & 1311 & 1286 & 1174 & 1253 & 1278 & 1134 \\
\hline YS (MPa) & 957 & 960 & 1101 & 884 & 927 & 1098 & 1224 & 1206 & 1127 & 1145 & 1123 & 1127 \\
\hline
\end{tabular}


a

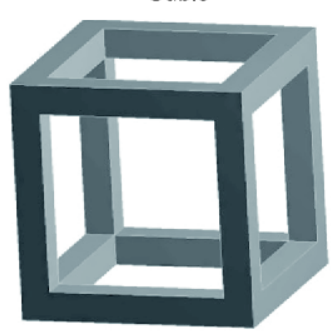

G7
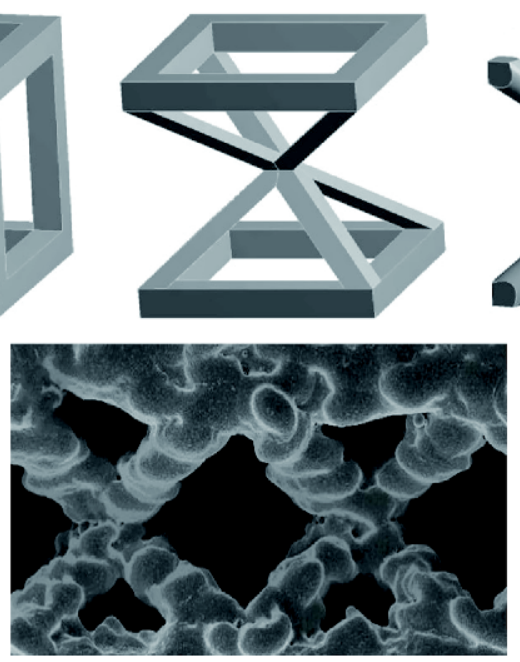

Stress-strain plots
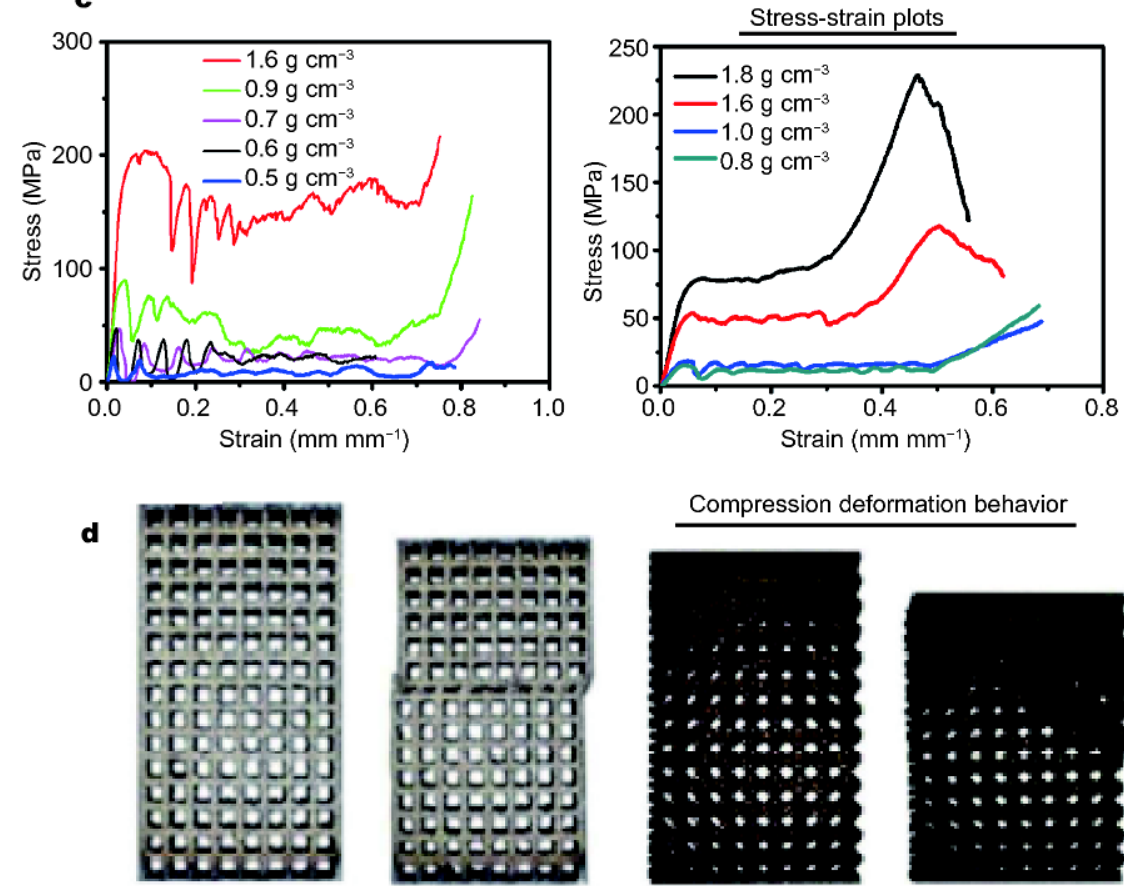

$\varepsilon=4 \%$

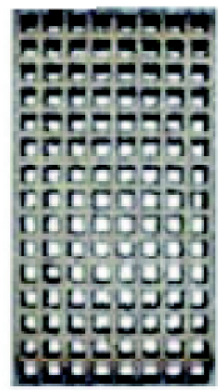

$\varepsilon=0 \%$ $\varepsilon=0 \%$

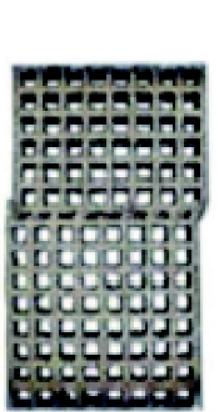

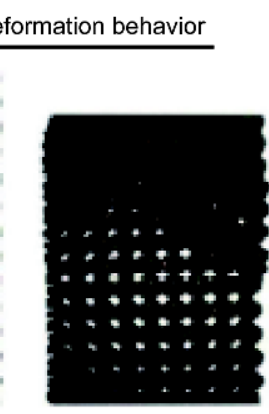

$\varepsilon=11 \%$
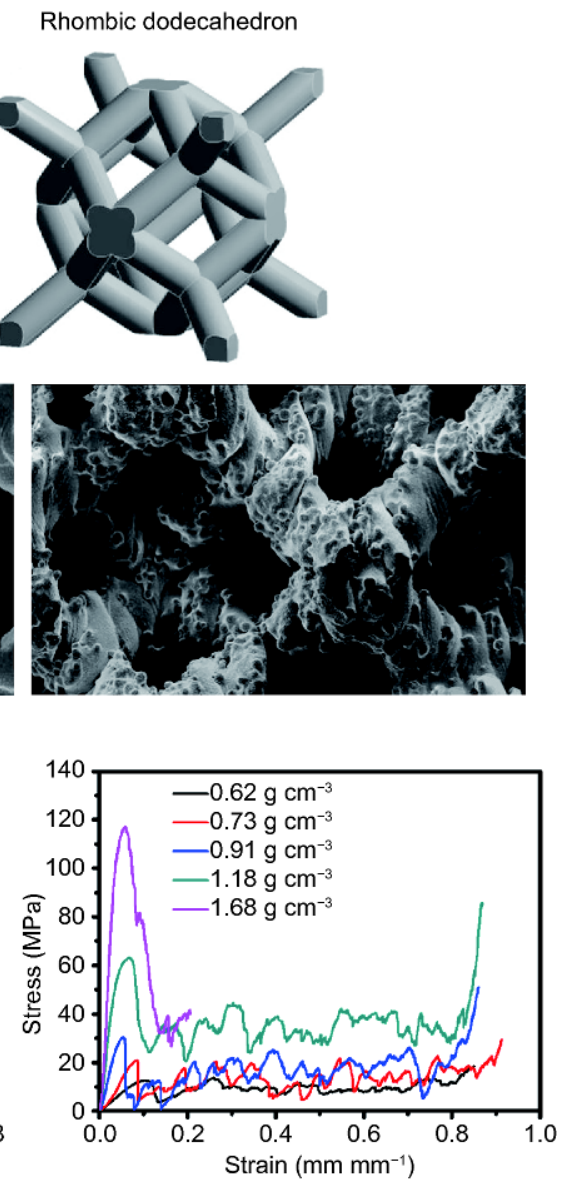

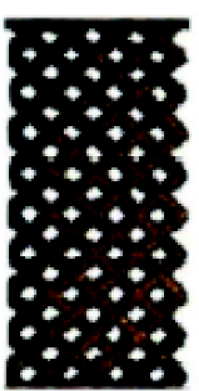

$\varepsilon=0 \%$

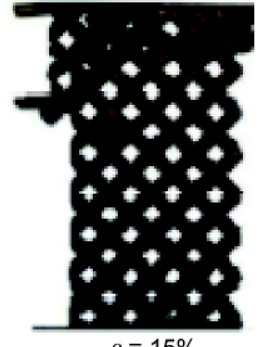

$\varepsilon=15 \%$

Figure 3 (a) CAD files and (b) scanning electron microscopy (SEM) graphs of different unit cell elements with (c) stress-strain plots showing brittle (cubic and rhombic dodecahedron) and ductile (G7) characteristics of unit cells. (d) Compression deformation behavior showing different deformation modes and angle of fracture/crush bands for cubic (bucking and 90), G7 (bending and 45), and rhombic dodecahedron (bending and 45) unit cell elements. Adapted from ref. [75], Copyright 2016, Elsevier.

$\sim 60 \mathrm{MPa}$ and $3.0 \pm 0.6 \mathrm{GPa}$, respectively in comparison to the Ti2448 alloy sample of $\sim 38 \mathrm{MPa}$ and $\sim 1.44 \pm$ $0.2 \mathrm{GPa}$. They concluded that $\beta$-type Ti2448 porous structure had at least twice strength-to-modulus ratio than $\mathrm{Ti}-6 \mathrm{Al}-4 \mathrm{~V}$ porous components with identical porosity, and was highly attractive for biomedical applica- tions.

\section{Role of scan speed}

The effect of scan speed in EBM on the surface and mechanical properties of the scaffolds was also studied [77]. Higher scan speeds, led to a rough strut surface with 
Table 2 List of properties of Ti-6Al-4V titanium alloy fabricated by EBM with different unit cell structures [75]

\begin{tabular}{|c|c|c|c|}
\hline Unit cell structures & Density $\left(\mathrm{g} \mathrm{cm}^{-3}\right)$ & Modulus (GPa) & Strength $(\mathrm{MPa})$ \\
\hline \multirow[t]{3}{*}{ Cubic } & 1.6 & 14.94 & 202 \\
\hline & 0.9 & 2.88 & 90 \\
\hline & 0.7 & 2.22 & 46 \\
\hline \multirow[t]{3}{*}{ G7 } & 1.6 & 2.39 & 52 \\
\hline & 1.0 & 1.46 & 18 \\
\hline & 0.8 & 1.23 & 15 \\
\hline \multirow[t]{3}{*}{ Rhombic dodecahedron } & 1.68 & 6.34 & 112 \\
\hline & 0.91 & 1.38 & 30 \\
\hline & 0.73 & 0.89 & 20 \\
\hline
\end{tabular}

pores/defects $(\sim 40 \mu \mathrm{m})$ because of partial sintering of particles. It was observed that lower electron beam scan speed $\left(150 \mathrm{~mm} \mathrm{~s}^{-1}\right)$ led to more input energy, which produced strong struts with less number of pores/defects and smooth surface. This suggested that the surface properties can be tailored by adjusting the scan speed of the electron beam. Other researchers observed that the orientation during the building process had an influence on surface roughness because of change in energy flow $[78,79]$.

Role of complex design architectures (Graded/Gradient) The natural bone has a functionally graded structure. The outer dense region referred as cortical bone has elastic modulus of $\sim 15-25 \mathrm{GPa}$, while the inner porous region referred as cancellous bone has an elastic modulus of $\sim 0.1-4.5 \mathrm{GPa}$. There is a bone marrow cavity in the center $[1,80]$. Thus, to obtain a replica of natural bone, 3D scaffolds with graded porosity were studied, since porosity is related to the elastic modulus according to Gibson-Ashby equation: $E=E_{0}\left(\rho / \rho_{0}\right)^{2}[81]$. In this regard, titanium alloy rod with graded density, characterized by a lower density inner foam (density $\sim 0.6 \mathrm{~g} \mathrm{~cm}^{-3}$; stiffness $\sim 0.3 \mathrm{GPa}$ ), surrounded by a foam with relatively higher density $\left(\sim 1.1 \mathrm{~g} \mathrm{~cm}^{-3}\right.$; stiffness $\left.\sim 2.2 \mathrm{GPa}\right)$ was fabricated [28].

Graded/gradient porous structures are envisioned to provide optimum combination of elastic modulus, strength and toughness. Recent studies focused on bone ingrowth suggested that the cellular structures should have high degree of porosity. However, highly porous structures are expected to have low mechanical strength. It is absolutely essential that cellular structures are characterized by adequate strength and ductility combination in conjunction with the ability to absorb high energy [1]. In this regard, a complex structure mimicking bone in- volving graded/gradient Ti-6Al-4V mesh structure using EBM was fabricated [82]. It was observed that graded and uniform mesh structures had an elastic regime up to the peak stress, followed by a plateau region, where the stress fluctuated (Fig. 4). Furthermore, it was noted that both low and high density regions of the graded mesh structure first experienced uniform deformation, followed by fracture in the low density region, when crush band was formed. Finite element analysis (FEA) was used to indicate stress concentration regions in the mesh and a discontinuous stress transfer was noted in graded materials at the nodes, but not in the gradient material (Fig. 5) [82]. This study outlined the advantage of gradient mesh design over graded and uniform mesh design, which avoids the weakness of brittle behavior and is characterized by high strength-high ductility combination and high energy absorption.

\section{Role of post-fabrication heat treatment}

Several post-fabrication treatments such as stress relieving, surface heat treatment, and hot isostatic pressing (HIP) have been explored for porous scaffolds $[83,84]$. The process of annealing or aging implemented after fabrication led to a different microstructure, where the mechanical properties are sensitive to the microstructure [85]. It was observed that the annealed sample consisted of single $\beta$ phase and exhibited large plasticity, low Young's modulus and good fatigue properties. On aging, precipitation of a phase occurred that increased the hardness, strength and Young's modulus and at low stress, cyclic ratcheting was the primary factor that led to fatigue failure [85].

\section{Role of post-fabrication surface modification}

Recently, several surface modification methods have been explored on porous scaffolds to promote cellular inter- 

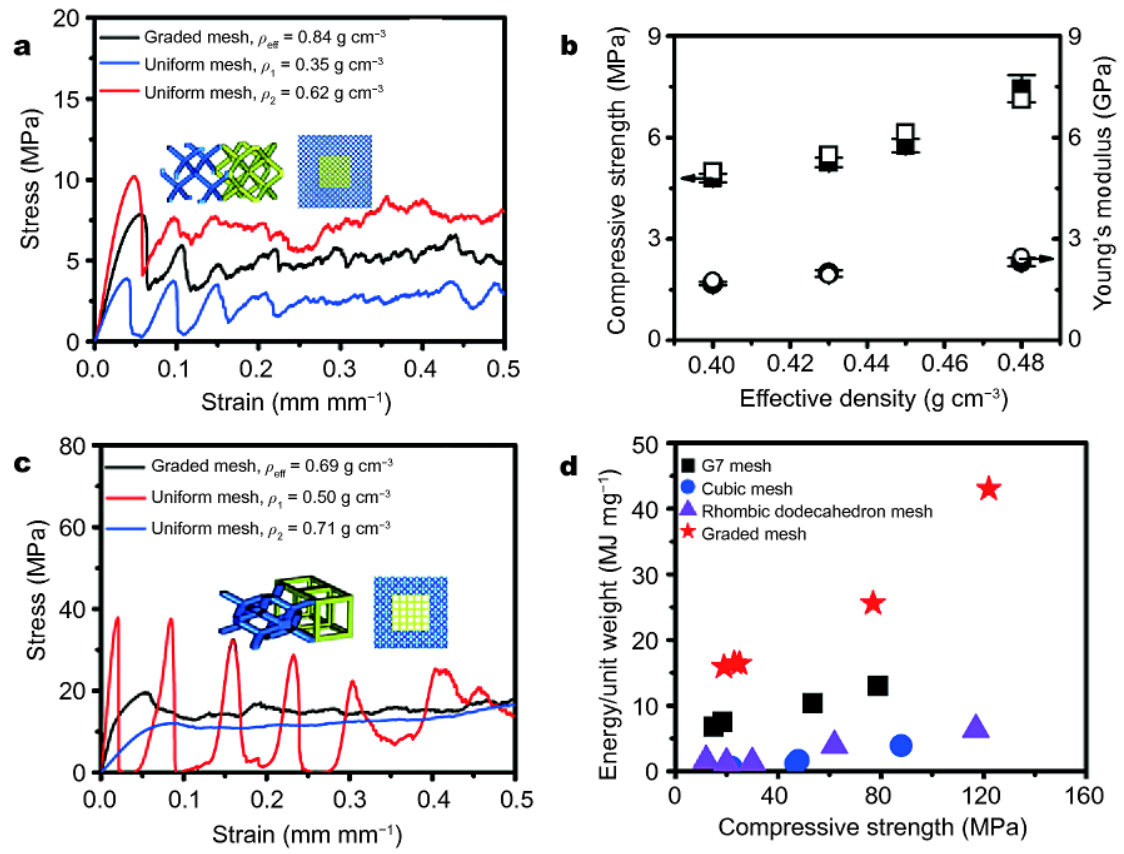

Figure 4 (a, c) Compression stress-strain plots of graded mesh structure, (b) compressive strength and Young's modulus as a function of effective density (experimental: solid symbols; and theoretical: open symbols), and (d) energy density/unit weight as a function of compressive strength (effective density, $\rho_{\text {eff }}$ is defined as: $\rho_{\text {eff }}=\rho_{1} f_{1}+\rho_{2} f_{2}$, where $f$ is the volume fraction of uniform mesh constituent, and subscripts 1 and 2 denote each constituent respectively). Aadapted from ref. [82], Copyright 2016, Wiley.

actions with the host tissue, beyond what is obtained by 3D printing. However, to obtain uniform surface modification on $3 \mathrm{D}$ cellular structure is a challenge. In this regard, the traditional surface treatment methods such as grinding, grit blasting, ion implantation, thermal spraying, etc. cannot be employed because they do not help in obtaining a homogeneous surface modification throughout the entire structure [86-90]. Hence, the recent focus was on chemical and/or electrochemical methods because acid-based solution can penetrate through the porous structures through the interconnected pores, producing a homogeneous surface throughout the entire structure [86,91-93]. Micro-arc oxidation was observed not to influence the mechanical properties such as maximum stress, yield stress, plateau stress, and energy absorption, but had a significant effect on the elastic modulus. Mechanical properties were significantly affected and decreased in scaffolds with higher relative densities [93]. A combination of chemical etching and electrochemical polishing of porous structures as a post-fabrication surface modification step led to an increase in internal porosity and a decrease in effective strut thickness resulting in overall decreased mechanical properties [86]. In another study, acid-alkali surface treatment induced substantial mass loss and, hence, significant loss of both static and fatigue properties [94]. Thus, large surface area of $3 \mathrm{D}$ printed porous scaffolds, was responsible for a significant impact on mechanical properties induced by surface modification.

Irrespective of the above, an improvement in fatigue strength was noticed on chemically etching with same etchant compared to the as-fabricated samples of Ti-6Al$4 \mathrm{~V}$ alloy, but not in the case of CoCrMo alloy $[83,84]$. The differences were attributed to low notch (surface roughness and micro-pitting after etching) sensitivity of CoCrMo alloy with more ductility than Ti-6Al-4V alloy. Given that the notch is a stress raiser, the fatigue properties were improved in a $\mathrm{Ti}-6 \mathrm{Al}-4 \mathrm{~V}$ alloy after etching because of reduced surface roughness and removal of partially melted powder particles. In contrast, in CoCrMo alloy, while the particles were removed, micro-pits were formed on the surface, leading to insignificant difference in surface roughness. Thus, selecting an appropriate etchant and exposure time is important to enhance mechanical properties.

\section{Part II: Biocompatibility and biological response -influence of surface modification}

A practical approach to alleviate the undesired biomechanical mismatch is to use a $3 \mathrm{D}$ interconnected 


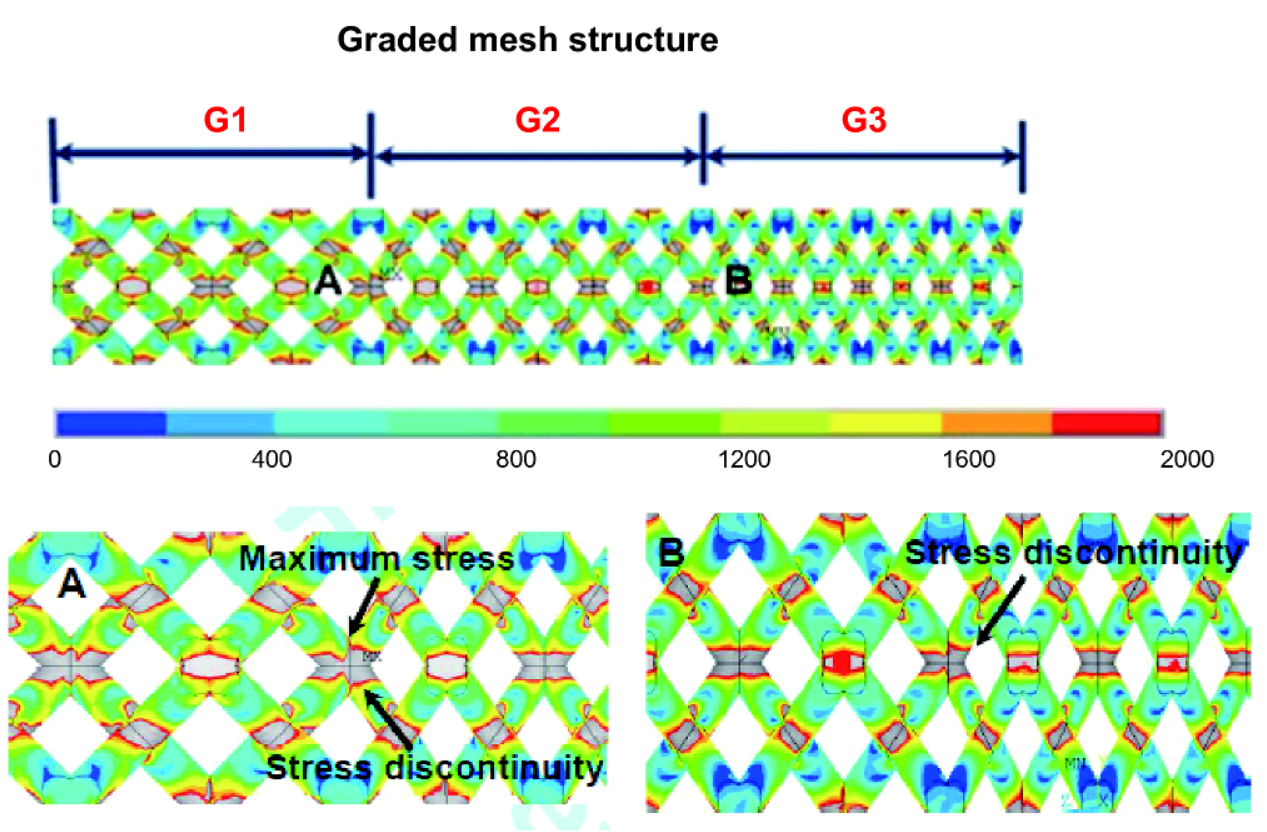

\section{Gradient mesh structure}
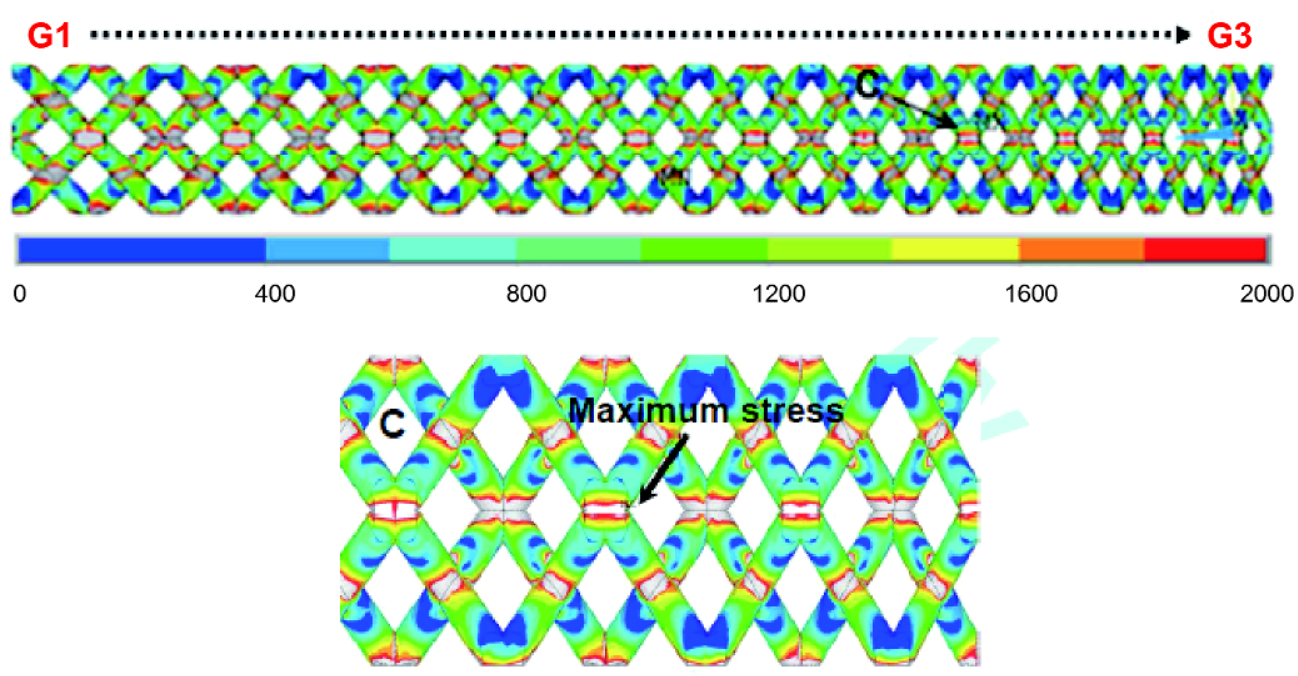

Figure 5 Finite volume method (FVM) stress analysis of graded and gradient mesh structures performed using ANSYS software, indicating the stress discontinuity along the interface between the two different layers in graded mesh (G1-G2 and G2-G3) during deformation. Such discontinuities were absent in gradient mesh structures. Adapted from ref. [82], Copyright 2016, Wiley.

porous foam or mesh structure, which will have a significantly low modulus compared to a solid and dense implant. Recently, the interplay between 3D printed foam and mesh structure and osteoblast functions were studied and compared with a solid Ti-6Al-4V alloy $[1,95,96]$. As expected, the seeding efficiency was low for both mesh and foam structures, but there was significant cell spreading and cell bridging of osteoblasts (MC3T3-E1). Fig. 6 illustrates morphology of osteoblasts on mesh and foam structures $[1,95,96]$. The alkaline phosphate (ALP) assay results suggested that the enzyme activity increased with time for foam and mesh structures, irrespective of pore size.

The response of different cells to pore size varies [97]. For example, pore size of $\sim 5-15 \mu \mathrm{m}$ was considered suitable for fibroblast, $\sim 70-120 \mu \mathrm{m}$ for chondrocytes, $\sim 100-$ $400 \mu \mathrm{m}$ for osteoblast ingrowth [19,98-100]. Moreover, interconnected porous structures with gradient distribu- 


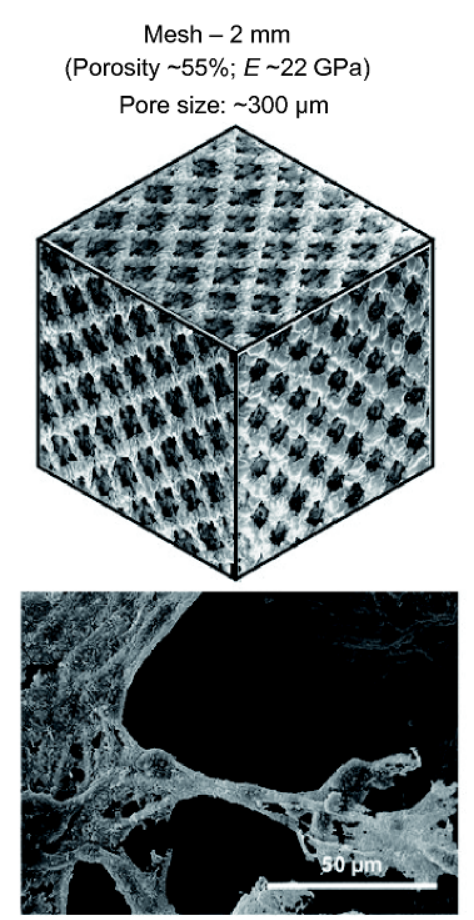

Foam - 1X

(Porosity 76\%; E 6 GPa) Pore size: $\sim 700 \mu \mathrm{m}$
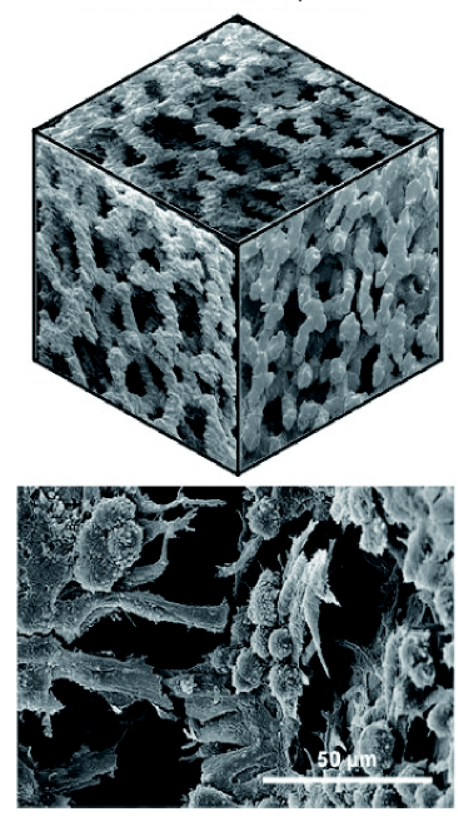

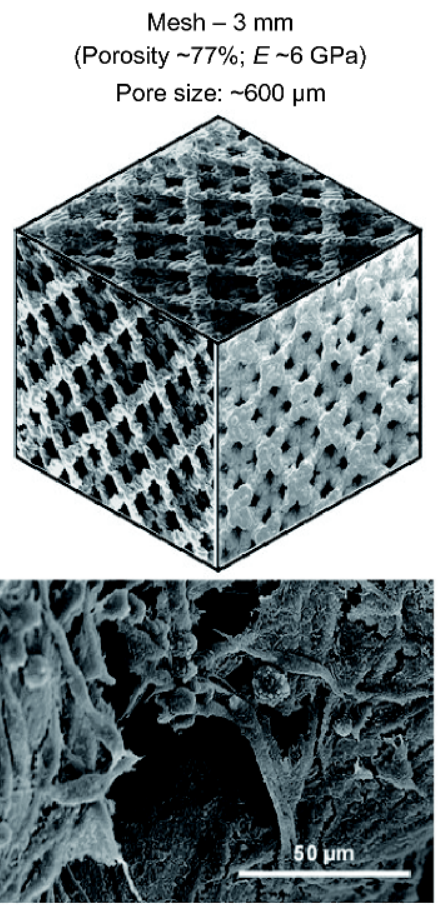

Foam $-2 \mathrm{X}$

(Porosity 85\%; E 2 GPa) Pore size: $\sim 1000 \mu \mathrm{m}$
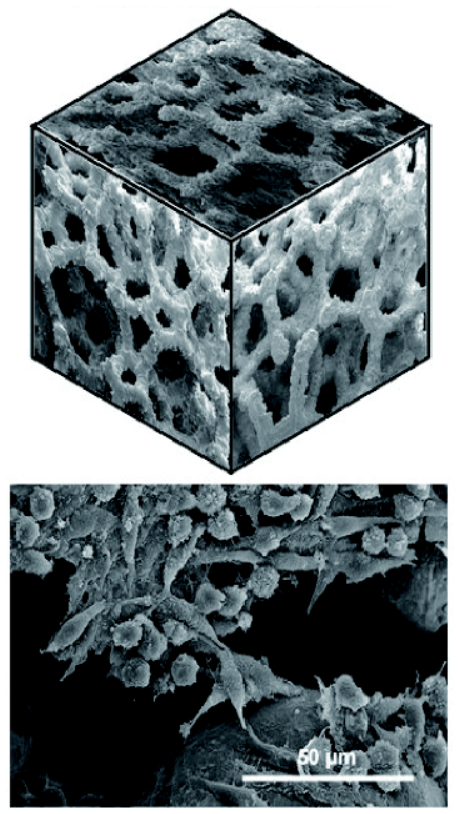

\author{
Mesh - $4 \mathrm{~mm}$ \\ (Porosity $\sim 85 \%$; E 2.5 GPa) \\ Pore size: $\sim 900 \mu \mathrm{m}$
}
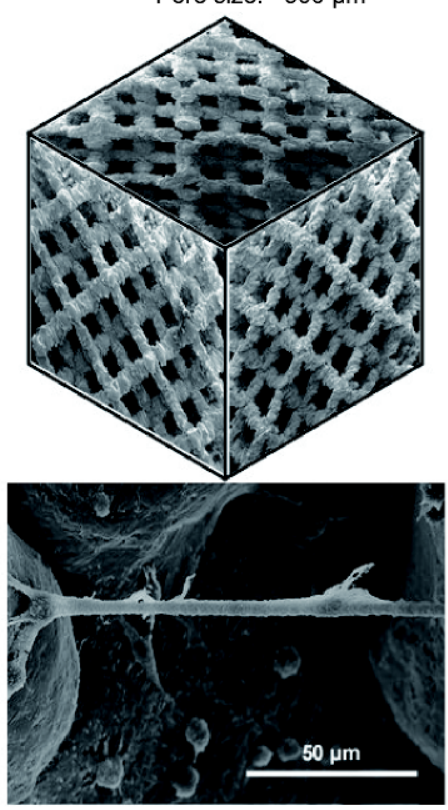

Foam - 3X

(Porosity 90\%; E 1 GPa)

Pore size: $\sim 1500 \mu \mathrm{m}$
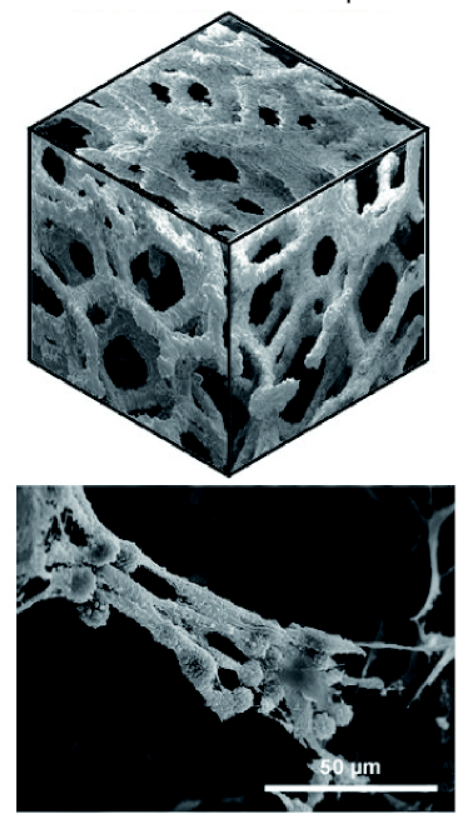

Figure 6 Representative SEM graphs of Ti-6Al-4V mesh and foam structures with different porosity fabricated by EBM and corresponding osteoblast function. Adapted from ref. [95], Copyright 2014, American Scientific Publishers; and ref. [96], Copyright 2015, Wiley.

tion of pores can repair and reconstruct more than one tissue, even though the microenvironment varies for different tissues [1]. For instance, functionally graded porous titanium alloy fabricated to meet the requirements of tissue engineering and to reduce stress shielding and high energy absorption indicated that the structure facilitated flow of nutrients and cell proliferation across the entire structure $[101,102]$. It was concluded that the 


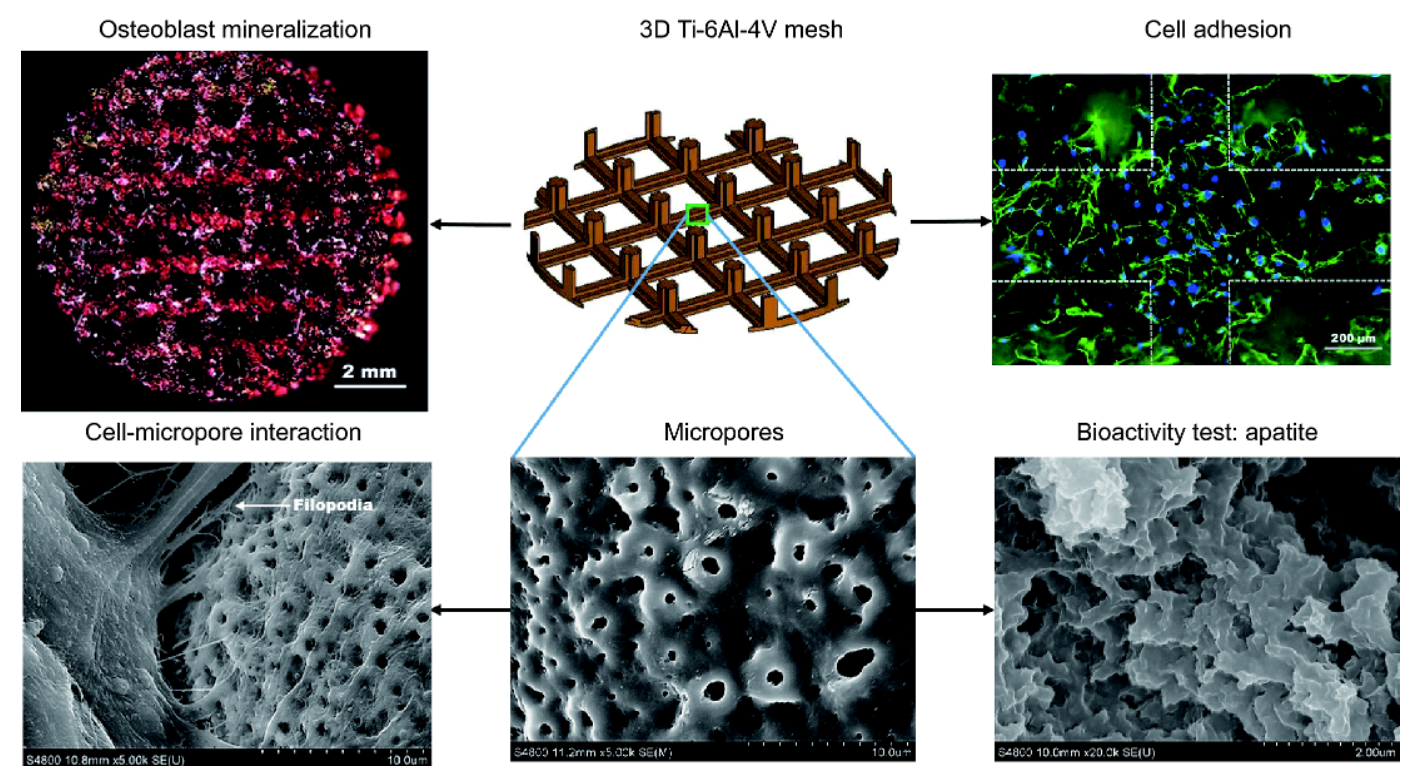

Figure 7 2D CAD profile of micro-arc oxidized Ti-6Al-4V alloy mesh structure illustrating the SEM morphology of micropores grown on the strut surface, bioactive apatite formation, and osteoblast-micropore interaction. Also presented are the fluorescent micrograph representing cell adhesion and expression of extracellular fibronectin, and optical micrograph of mineralized scaffold. Adapted from ref. [91], Copyright 2016, Wiley.

various stages of cell maturation can co-exist in different regions of the gradient mesh structure.

\section{Surface modification of $3 D$ printed structures}

To enhance the cell-material interaction and osseointegration potential beyond what is possible via $3 \mathrm{D}$ architecture, surface modification is being explored. A number of studies have been conducted on Ti-6Al-4V cellular structures fabricated by EBM to study biocompatibility of surface modified structures. One such study focused on determining the suitability of different Ti-6Al-4V surfaces produced by EBM as a matrix for attachment, proliferation, and differentiation of osteoblasts [103]. It was noted that osteoblast proliferation and differentiation can be changed by modifying the surface characteristics of $\mathrm{Ti}$ $6 \mathrm{Al}-4 \mathrm{~V}$ mesh. Titanium alloy was observed to provide a highly favorable surface for osteoblast adhesion and osteogenic differentiation. In another study, it was shown that the oxide layer adsorbed fibronectin promoted osteoblast attachment and osteointegration through binding of adsorbed fibronectin to surface-expressed osteoblast integrins [104]. Studies also reported the influence of surface nanotopography on the enhanced expression of osteogenic markers [105-107].

More recently, mesh structures were modified via micro-arc oxidation and anodization approach (Figs 7 and 8) $[96,97]$. The combination of macro-, micro-, and nanoporous architecture obtained in the surface modified
Ti-6Al-4V mesh structures mimicked natural bone-like ECM topography that promotes bone formation at nanoscale (regulating protein conformation and signal transduction) and microscale (impacting initial cell attachment and proliferation) [83,108-117]. The unique combination of microporous/nanoporous bioactive titania and interconnected porous architecture of microarc/ anodized titanium alloy mesh structures provided a multimodal surface roughness from nano-to-micro-tomacroscale regime and increased the bioactivity of the asfabricated mesh structure $[91,92]$. This provided a favorable osteogenic microenvironment for tissue ingrowth and is envisioned to facilitate stronger primary and secondary fixation of the implant device. The interconnected porous architecture also enables circulation of physiological fluid, oxygen, nutrients, and cells and mimics the flow conditions of natural bone. Additionally, in the context of long term structural integrity, the transport of cells through the porous mesh structure helps in mechanical interlocking because the confluent sheet connects the pores and integrates with the structure [91,92].

The coating of 3D titanium implants with tantalum and chitosan-hydroxyapatite composite improved diabetesinduced impaired osteogenesis of these implants $[118,119]$. While evidence of clinical studies indicated high failure rate for titanium implants in diabetic patients, where reactive oxygen species (ROS) were produced at the implant/bone interface [120-122]. Diabetes- 


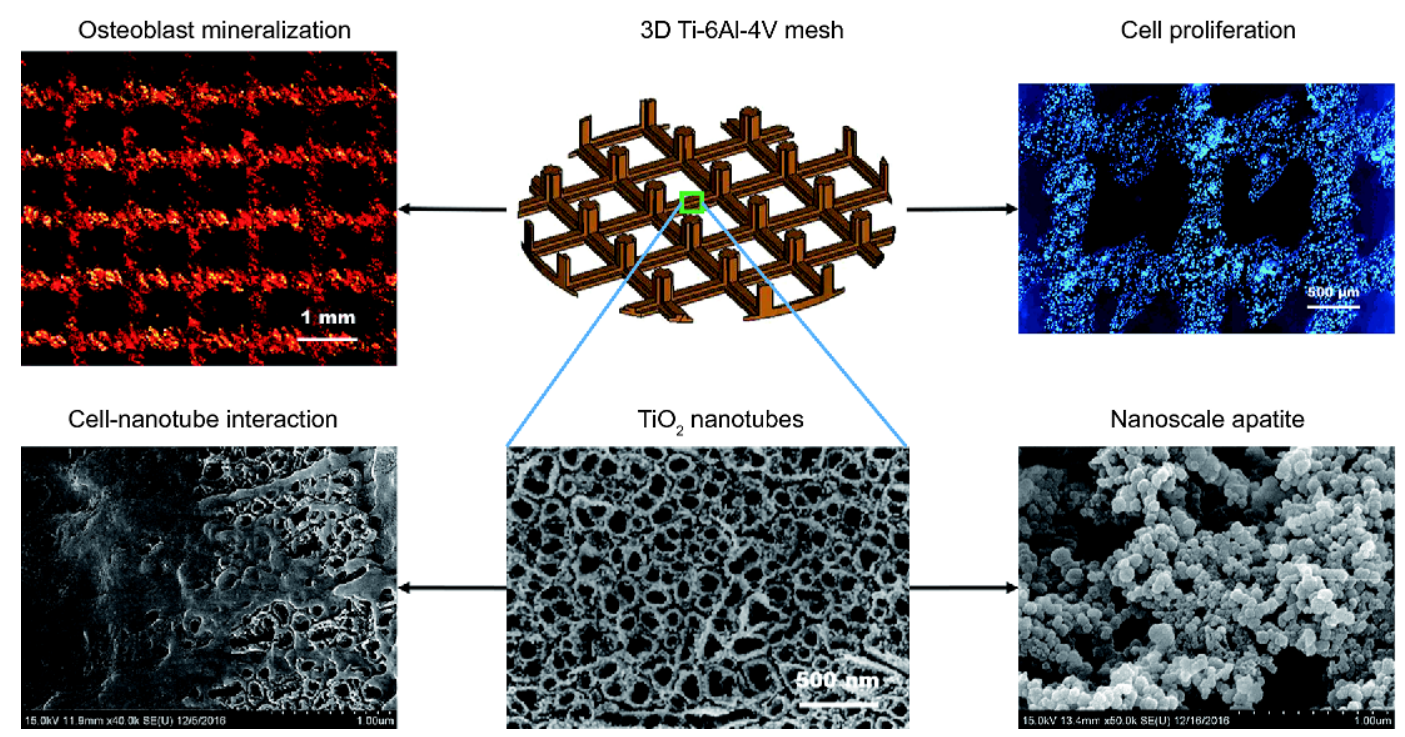

Figure 8 2D CAD profile of anodized Ti-6Al-4V alloy mesh structure illustrating the SEM morphology of nanotubes grown on the strut surface, bioactive nanoscale apatite formation, and osteoblast-nanotube interaction. Also presented are the fluorescent micrograph representing cell proliferation and optical micrograph of mineralized scaffold. Adapted from ref. [92], Copyright 2016, Elsevier.

induced accumulation of ROS also influenced the viability of cells on the titanium surface [123]. In this regard, tantalum coating on titanium indicated superior integration of tissue in diabetes mellitus impaired osteogenesis in sheep by suppressing the ROS-mediated p38 MAPK pathway. In a similar way, studies performed by chitosan-hydroxyapatite composite coating on 3D mesh structures improved diabetes-induced impaired osteointegration via the reactivation of $\mathrm{Wnt} / \beta$-catenin pathway [118]. Contrary to the aforementioned benefits, coatings were believed to loosen the biomaterial/coating interface because of inherent brittleness and poor adhesion [124-126].

In another study, the Ti-6Al-4V mesh structures fabricated by EBM technique were biologically surface modified using BMP-2 (bone morphogenetic protein-2) and decellularized extracellular matrix. The bioactivity of the surface was improved and the modified surface was expected to enhance the fixation of the implant with the surrounding bone and improve the long-term stability $[127,128]$.

\section{Biological surface modification: incorporation of}

therapeutic drugs into $3 D$ printed architectures

The incorporation of osteoinductive growth factors such as bone morphogenetic proteins (BMP) into 3D printed mesh structures or surface treatment of 3D mesh structures with BMP can be considered as viable approaches to increase osteoinductivity and facilitate bone tissue re- generation in the scaffold. Incorporation of other drugs such as dexamethasone, hydrogels, simvastatin, antimicrobial agents, and VEGF has also been explored [127130].

The potential role of topography of the material in determining the molecular assembly of BMP-2 and subsequent osteoblast functions indicated a significant difference in organization and assembly of protein [127]. It was proposed that $300 \mu \mathrm{m}$ pore size mesh structure with interconnected porous architecture was superior to mesh structures with $600 \mu \mathrm{m}$ and $900 \mu \mathrm{m}$ pore size respectively, in terms of cell proliferation and mineralization. Also, a favorable effect of pore size on protein adsorption was noted, which led to the formation of small and dense dendrites of protein on mesh structures, that provided a favorable osteogenic microenvironment. It was envisaged that the unique microstructure of mesh along with preadsorbed protein (BMP-2) provided the conditions favorable for bone tissue formation in terms of cell adhesion, proliferation, expression level of proteins, and mineralization. On incorporating BMP-2, the osteoinductive potential of the material was increased, influencing cell signaling cascade to differentiate osteoblast cells into a more matured osteogenic phenotype. In another study, 3D printed scaffolds containing proteins were observed to successfully deliver BMP-2 that promoted bone formation in relation to scaffold without BMP-2 [1,131]. More recently, the advances in printing technology have provided an opportunity to load drugs 
during post-fabrication surface treatment [132-135].

It is pertinent to indicate that vascularization directly impacts in vivo bone formation. In reality, scaffolds with interconnected porous structure and with pore size of $\sim 300-400 \mu \mathrm{m}$ are favorable for the ingrowth of blood capillaries $[1,136,137]$. Thus, the long-term success of a 3D scaffold under in vivo conditions is largely governed by the effectiveness of the scaffold to support angiogenesis [138-140]. Angiogenesis refers to new blood capillaries that are formed from pre-existing blood vessels at the host site. Vascularization occurs during wound healing $[1,141]$ and is a slow process, requiring several days or weeks for it to completely take place in porous scaffolds with interconnected pores [140,141]. When there is insufficient vascular network, the cells experience a condition of hypoxia/necrosis because of restricted supply of oxygen/nutrients [142]. The amount of oxygen that is supplied to the cells, is governed by the diffusion length, which is $\sim 150-200 \mu \mathrm{m}$ from the blood vessel [141-146]. A primary limitation associated with 3D scaffold vascularization is adequate supply of blood in the center of scaffolds, when the blood capillaries are absent [140]. For instance, rapid growth of blood vessels occurs in scaffolds with pore size greater than $\sim 250 \mu \mathrm{m}[1,147]$. Additive manufacturing that allows fabrication of $3 \mathrm{D}$ scaffolds with predefined architecture, is most likely to enable cell alignment, spatial organization of cells, tune porosity with respect to mechanical properties and vascularization $[1,52,148-150]$. On the other hand, conventional methods such as freeze casting, gas foaming, and particle leaching that produce a porous architecture with random distribution of pores results in a torturous pathway for new blood capillaries $[1,151]$. This slowdowns the growth of blood capillaries and transport of nutrients and oxygen $[1,141]$.

In the case of large scaffolds, pre-treatment is generally preferred for rapid growth of blood capillaries. To accomplish this, growth factors such as vascular endothelial growth factor (VEGF) play a role in angiogenesis and faster healing $[1,152,153]$. Furthermore, vascularization provides osteoprogenitor cells at the defect site, promoting new bone formation [154,155]. To ensure that vascularization occurs at the center of the 3D scaffold, pre-seeding of scaffolds with endothelial cells was proposed $[156,157]$. As a consequence, a link is established between the blood vessels of host tissues and endothelial cells which promotes vascularization. Furthermore, coating of endothelial cells and VEGF encourages the formation of blood vessels and promotes new bone formation $[1,158]$. The development of vascular and circu- lation networks is important for homeostasis and the regeneration ability of the bone. Based on the aforementioned findings, the future of bone tissue engineering will depend on developing tissue specific porous $3 \mathrm{D}$ scaffolds and incorporate the recent findings to ensure tissue regeneration [1].

\section{IN VIVO STUDIES AND CLINICAL TRIALS OF EBM FABRICATED 3D SCAFFOLDS}

$3 \mathrm{D}$ printed titanium alloy mesh structure scaffolds have the potential to restore anatomically complex patient specific areas such as spinal fusion, dental, temporomandibular joint and craniomaxillofacial surgery $[159,160]$. Spinal fusion mesh/cage devices were introduced in 1988 to attain spine interbody (cervical disk) fusion and are now widely practiced. Interbody fusion cage made of poly-ether-ether-ketone (PEEK) was used for spinal disorder treatment. But, it does not integrate well with surrounding bone tissue and forms fibrous tissue capsule. To overcome this disadvantage, $3 \mathrm{D}$ porous Ti mesh/cage using EBM, was developed [160]. Research is in progress to $3 \mathrm{D}$ print titanium alloys to produce customized titanium prosthesis in limb salvage surgery to replace bones lost due to sarcoma [161]. Studies have demonstrated that porous $\mathrm{Ti}$ implants into the frontal skull of domestic pigs exhibited enhanced bone formation within the implant [162].

The 3D mesh/cage constructs provide necessary support for cells to proliferate and differentiate. They are believed to be a good choice for bone regeneration and hard tissue replacement $[58,163]$. The control of pore size, pore geometry and porosity distribution, cell behavior in vitro and in vivo environments were significantly improved and good biocompatibility was obtained $[18,164-166]$. It was shown that pore size in the range of 300-900 $\mu \mathrm{m}$ using EBM-fabricated mesh provided favorable condition for cell differentiation at an early stage, and bone cells adhered to the struts and ligaments of mesh by forming numerous cytoplasmic extensions [95]. Within 21 days, bone cells colonized the entire architecture bridging the pores. For these architectures, the stiffness for Ti-6Al-4V implants was in the range of 2-20 GPa, appropriate for elimination of stress shielding.

A recent in vivo study on porous $\mathrm{Ti}$ mesh/cage fabricated by EBM and implanted at cervical disc levels (C3/ C4 or C4/C5), in 12 mature female Small Tail Han sheep (1-2 years old, $35-50 \mathrm{~kg}$ ) indicated that rapid bone ingrowth is a possibility, together with superior osseointegration and mechanical stability. This demonstrated their 
Animal tests: anterior cervical fusion
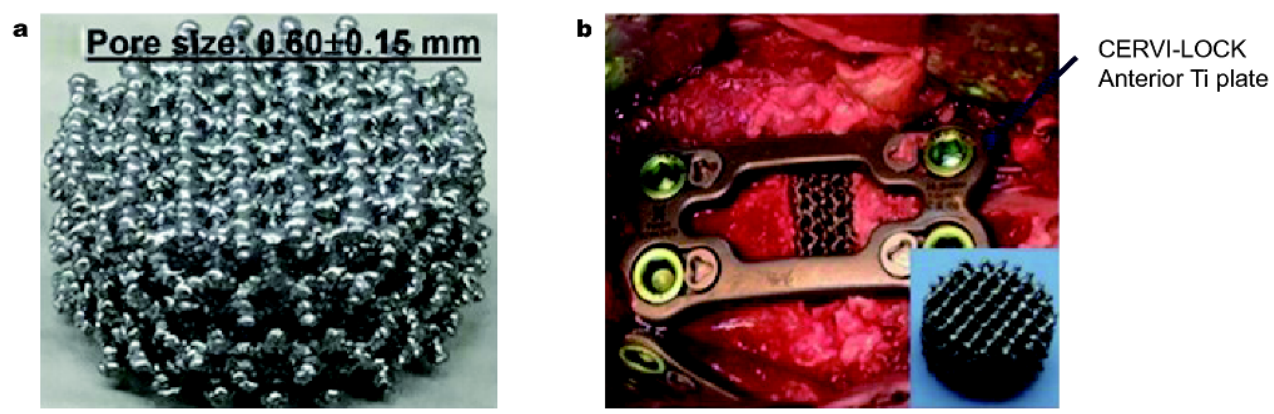

Radiographic analysis after 3 months
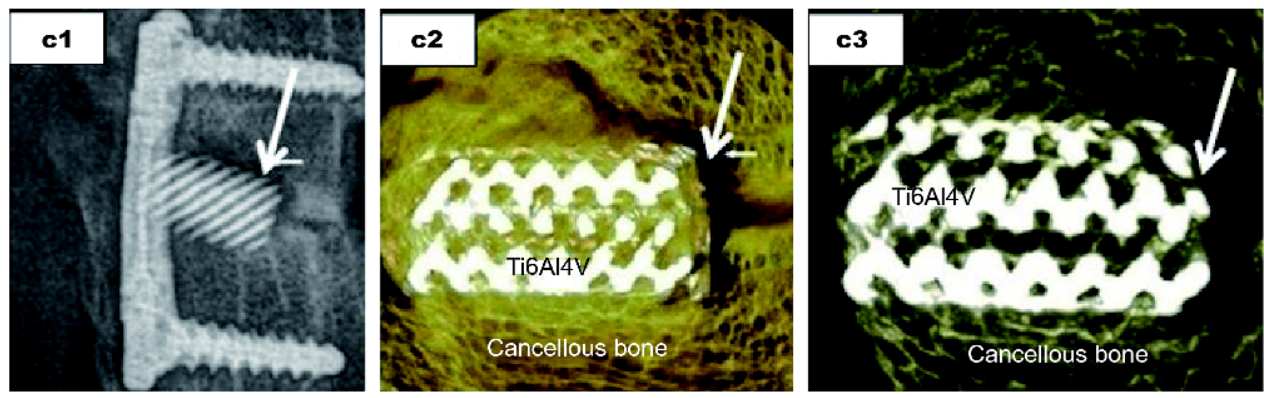

Histologic analysis after 3 months
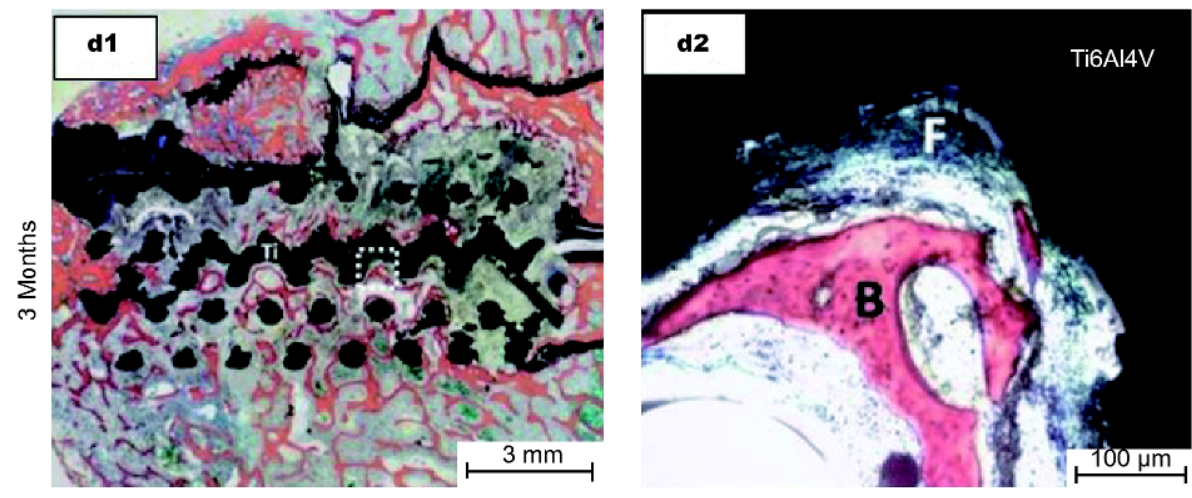

Figure 9 (a) Low magnification digital image of 3D printed porous Ti-6Al-4V titanium alloy mesh implant with an average pore size of $600 \mu \mathrm{m}$ fabricated by EBM, (b) implantation of mesh implant in a mature Small Tail Han sheep (1-2 years, 35-50 kg) to fuse two cervical discs in the anterior region of the spine, and (c) radiographic analysis after 3 months in a mature Small Tail Han sheep representing radiolucent interface gap (white arrows) in (c1) X-ray, (c2) computer-generated image of thick section, and (c3) computer-generated image of thin section. (d) Histological analysis after 3 months in a mature Small Tail Han sheep representing significant extent of bone formation (B) and growth of fibrous tissue (F) inside the pores of the implant. Adapted from ref. [160], Copyright 2017, Springer.

potential for clinical application in comparison to PEEK [160]. After three months, post-implantation, micro CT (computer generated) imaging and histological staining showed the growth of neighboring bone tissue into porous Ti mesh, partially fusing the two vertebral bodies. The bone tissue bonded closely with $\mathrm{Ti}$ mesh/cage, with majority of bone tissue around the struts in the interior and peripheral regions of the mesh (Fig. 9) [160]. A comparative study showed that the culture of human osteoblast-like cells on Ti-6Al-4V led to enhanced osteogenic differentiation in comparison to PEEK implant [167].

The 3D-printed titanium mesh implants have also been shown to be excellent candidates for the repair of bifrontal skull defects and maxillary and orbital floor reconstruction $[168,169]$. The 3D architecture provides improved stability after fixation of mandibular fracture, compared to the plates and screws because of their 3D configuration instead of greater plate thickness or screw length [170]. This is supposed to facilitate good blood supply to the bone tissue. More recently, clinical trials of 
bimaxillary surgery and mandibular reconstruction using EBM fabricated titanium alloy on a woman has also shown highly encouraging results [171]. In summary, the EBM is potentially a valuable tool to fabricate patient specific prosthesis with complex shapes/architectures and internal features, that can precisely match the bone tissueimplant interface and contribute to the improvement in the quality of life of the patient.

\section{CONCLUSIONS}

The process-structure-property relationships in three-dimensional implantable titanium alloy biomaterials processed by EBM is elucidate here. EBM has the benefit of processing patient-specific complex designs, which can be either obtained from the CT scan of the defect site or through a CAD program. We have summarized the evolution and underlying reasons that have motivated $3 \mathrm{D}$ printing of scaffolds for tissue regeneration. There are two parts of review for obtaining ultimate functionalities. The first part focuses on obtaining the ultimate functionalities in terms of mechanical properties of 3D titanium alloy scaffolds fabricated by EBM with different characteristics based on design, unit cell, processing parameters, scan speed, porosity, and heat treatment. The second part focuses on the advancement of enhancing biological response of these 3D scaffolds and the influence of surface modification on cell-material interactions. In the end a discussion on the clinical trials of these 3D porous scaffolds illustrates their potential in meeting the current needs of the biomedical industry.

Received 15 August 2017; accepted 29 September 2017; published online 14 December 2017

1 Kumar A, Nune KC, Murr LE, et al. Biocompatibility and mechanical behaviour of three-dimensional scaffolds for biomedical devices: process-structure-property paradigm. Int Mater Rev, 2016, 61: 20-45

2 Schubert C, van Langeveld MC, Donoso LA. Innovations in 3D printing: a 3D overview from optics to organs. Br J Ophthalmol, 2014, 98: 159-161

3 Simancik F. Introduction: the strange world of cellular metals. In: Degischer HP, Kriszt B (Eds). Handbook of cellular metals. Weinheim: Wiley-VCH Verlag, 2002, 1-4

4 Weber JN, White EW. Carbon-metal graded composites for permanent osseous attachment of non-porous metals. Mater Res Bull, 1972, 7: 1005-1016

5 Klawitter JJ, Weinstein AM. The status of porous materials to obtain direct skeletal attachment by tissue ingrowth. Acta Orthop Belg 1974, 40: 755-765

6 White EW, Weber JN, Roy DM, et al. Replamineform porous biomaterials for hard tissue implant applications. J Biomed Mater Res, 1975, 9: 23-27
7 Spector M, Michno MJ, Smarook WH, et al. A high-modulus polymer for porous orthopedic implants: Biomechanical compatibility of porous implants. J Biomed Mater Res, 1978, 12: 665677

8 Klawitter JJ, Bagwell JG, Weinstein AM, et al. An evaluation of bone growth into porous high density polyethylene. J Biomed Mater Res, 1976, 10: 311-323

9 Cestero HJ, Salyer KE, Toranto IR. Bone growth into porous carbon, polyethylene, and polypropylene prostheses. J Biomed Mater Res, 1975, 9: 1-7

10 Homsy CA, Cain TE, Kessler FB, et al. Porous implant systems for prosthesis stabilization. Clin Orthop, 1972, 89: 220-235

11 Sauer BW, Weinstein AM, Klawitter JJ, et al. The role of porous polymeric materials in prosthesis attachment. J Biomed Mater Res, 1974, 8: 145-153

12 Hirschhorn J, McBeath A, Dustoor M. Porous titanium surgical implant materials. J Biomed Mater Res Symp, 1971, 2: 49-67

13 Galante J, Rostoker W, Lueck R, et al. Sintered fiber metal composites as a basis for attachment of implants to bone. J Bone Joint Surgery, 1971, 53: 101-114

14 Hahn H, Palich W. Preliminary evaluation of porous metal surfaced titanium for orthopedic implants. J Biomed Mater Res, 1970, 4: 571-577

15 Karagienes M. Porous metals as a hard tissue substitute. I. Biomedical aspects. Biomater Med Dev Artif Organs, 1973: 171-181

16 Ryan G, Pandit A, Apatsidis DP. Fabrication methods of porous metals for use in orthopaedic applications. Biomaterials, 2006, 27: 2651-2670

17 Brunette DM, Tengvall P, Textor M, et al. Titanium in medicine: materials science, surface science, engineering, biological responses and medical applications. Berlin: Springer, 2001

18 Karageorgiou V, Kaplan D. Porosity of 3D biomaterial scaffolds and osteogenesis. Biomaterials, 2005, 26: 5474-5491

19 Bobyn JD, Stackpool GJ, Hacking SA, et al. Characteristics of bone ingrowth and interface mechanics of a new porous tantalum biomaterial. J Bone Joint Surgery, 1999, 81: 907-914

20 Hacking SA, Bobyn JD, Toh KK, et al. Fibrous tissue ingrowth and attachment to porous tantalum. J Biomed Mater Res, 2000, 52: 631-638

21 Bobyn JD, Pilliar RM, Binnington AG, et al. The effect of proximally and fully porous-coated canine hip stem design on bone modeling. J Orthop Res, 1987, 5: 393-408

22 Bronzino JD (Ed), The Biomedical Engineering Handbook, Vol. 1, Boca Raton: CRC Press, 2000

23 Lemmons JE. Inorganic-organic combinations for bone repair. In: Christel P, Meumier A, Lee AJC (Eds). Biological and Biomechanical Performance of Biomaterials. Amsterdam: Elsevier, 1986, 51-57

24 Yang S, Leong KF, Du Z, et al. The design of scaffolds for use in tissue engineering. Part I. Traditional factors. Tissue Eng, 2001, 7: 679-689

25 Niinomi M. Mechanical biocompatibilities of titanium alloys for biomedical applications. J Mech Behav BioMed Mater, 2008, 1: $30-42$

26 Heinl P, Müller L, Körner C, et al. Cellular Ti-6Al-4V structures with interconnected macro porosity for bone implants fabricated by selective electron beam melting. Acta Biomater, 2008, 4: 15361544

27 Murr LE, Gaytan SM, Medina F, et al. Additive layered manufacturing of reticulated Ti-6Al-4V biomedical mesh structures by 
electron beam melting. In: McGoron AJ, Li CZ, Lin WC (Eds). Proceedings of 25th Southern Biomedical Engineering Conference, ICFMBE Proceedings, Heidelberg: Springer, 2009, 24: 23-28

28 Murr LE, Gaytan SM, Martinez E, et al. Next generation orthopaedic implants by additive manufacturing using electron beam melting. Int J Biomater, 2012, 2012: 1-14

29 Coelho PG, Hollister SJ, Flanagan CL, et al. Bioresorbable scaffolds for bone tissue engineering: optimal design, fabrication, mechanical testing and scale-size effects analysis. Med Eng Phys, 2015, 37: 287-296

30 Klammert U, Gbureck U, Vorndran E, et al. 3D powder printed calcium phosphate implants for reconstruction of cranial and maxillofacial defects. J Cranio-Maxillofacial Surgery, 2010, 38: 565-570

31 Wang J, Yang M, Zhu Y, et al. Phage nanofibers induce vascularized osteogenesis in 3D printed bone scaffolds. Adv Mater, 2014, 26: 4961-4966

32 Zhao S, Zhu M, Zhang J, et al. Three dimensionally printed mesoporous bioactive glass and poly(3-hydroxybutyrate-co-3hydroxyhexanoate) composite scaffolds for bone regeneration. J Mater Chem B, 2014, 2: 6106-6118

33 Jones AC, Milthorpe B, Averdunk H, et al. Analysis of 3D bone ingrowth into polymer scaffolds via micro-computed tomography imaging. Biomaterials, 2004, 25: 4947-4954

34 Silva GA, Coutinho OP, Ducheyne P, et al. Materials in particulate form for tissue engineering. 2. Applications in bone. J Tissue Eng Regen Med, 2007, 1: 97-109

35 Baker BM, Chen CS. Deconstructing the third dimension-how 3D culture microenvironments alter cellular cues. J Cell Sci, 2012, 125: 3015-3024

36 Guvendiren M, Burdick JA. Engineering synthetic hydrogel microenvironments to instruct stem cells. Curr Opin Biotech, 2013, 24: $841-846$

37 Kraehenbuehl TP, Langer R, Ferreira LS. Three-dimensional biomaterials for the study of human pluripotent stem cells. Nat Meth, 2011, 8: 731-736

38 Hutmacher DW. Biomaterials offer cancer research the third dimension. Nat Mater, 2010, 9: 90-93

39 Guo B, Lei B, Li P, et al. Functionalized scaffolds to enhance tissue regeneration. Regenerative Biomaterials, 2015, 2: 47-57

40 Dawson JI, Oreffo ROC. Bridging the regeneration gap: stem cells, biomaterials and clinical translation in bone tissue engineering. Archives Biochem Biophys, 2008, 473: 124-131

41 Kolk A, Handschel J, Drescher W, et al. Current trends and future perspectives of bone substitute materials-From space holders to innovative biomaterials. J Cranio-Maxillofacial Surgery, 2012, 40: 706-718

42 Place ES, Evans ND, Stevens MM. Complexity in biomaterials for tissue engineering. Nat Mater, 2009, 8: 457-470

43 Ebrahimkhani MR, Young CL, Lauffenburger DA, et al. Approaches to in vitro tissue regeneration with application for human disease modeling and drug development. Drug Discovery Today, 2014, 19: 754-762

44 Engler AJ, Sen S, Sweeney HL, et al. Matrix elasticity directs stem cell lineage specification. Cell, 2006, 126: 677-689

45 Pelham RJ, Wang YL. Cell locomotion and focal adhesions are regulated by substrate flexibility. Proc Natl Acad Sci USA, 1997, 94: 13661-13665 honeycombs for tissue engineering of cardiac anisotropy. Nat Mater, 2008, 7: 1003-1010

47 Roy TD, Simon JL, Ricci JL, et al. Performance of degradable composite bone repair products made via three-dimensional fabrication techniques. J Biomed Mater Res, 2003, 66A: 283-291

48 Chu TMG, Orton DG, Hollister SJ, et al. Mechanical and in vivo performance of hydroxyapatite implants with controlled architectures. Biomaterials, 2002, 23: 1283-1293

49 Kujala S, Ryhänen J, Danilov A, et al. Effect of porosity on the osteointegration and bone ingrowth of a weight-bearing nickeltitanium bone graft substitute. Biomaterials, 2003, 24: 4691-4697

50 Jin QM, Takita H, Kohgo T, et al. Effects of geometry of hydroxyapatite as a cell substratum in BMP-induced ectopic bone formation. J Biomed Mater Res, 2000, 52: 841-851

51 Koffler J, Kaufman-Francis K, Shandalov Y, et al. Improved vascular organization enhances functional integration of engineered skeletal muscle grafts. Proc Natl Acad Sci USA, 2011, 108: 14789-14794

52 Hollister SJ. Porous scaffold design for tissue engineering. Nat Mater, 2005, 4: 518-524

53 Hardy JG, Cornelison RC, Sukhavasi RC, et al. Electroactive tissue scaffolds with aligned pores as instructive platforms for biomimetic tissue engineering. Bioengineering, 2015, 2: 15-34

54 Kumar A, Nune KC, Misra R. Understanding the response of pulsed electric field on osteoblast functions in three-dimensional mesh structures. J Biomater Appl, 2016, 31: 594-605

55 Kumar A, Nune KC, Misra RDK. Electric field-mediated growth of osteoblasts-the significant impact of dynamic flow of medium. Biomater Sci, 2016, 4: 136-144

56 Pirvu T, Blanquer SBG, Benneker LM, et al. A combined biomaterial and cellular approach for annulus fibrosus rupture repair. Biomaterials, 2015, 42: 11-19

57 Kim DG, Huja SS, Tee BC, et al. Bone ingrowth and initial stability of titanium and porous tantalum dental implants. ImPlant Dentistry, 2013, 22: 399-405

58 Hutmacher DW. Scaffolds in tissue engineering bone and cartilage. Biomaterials, 2000, 21: 2529-2543

59 Kiran S, Nune KC, Misra RDK. The significance of grafting collagen on polycaprolactone composite scaffolds: processingstructure-functional property relationship. J Biomed Mater Res, 2015, 103: 2919-2931

60 Sachlos E, Czernuszka J. Making tissue engineering scaffolds work. Review: the application of solid freeform fabrication technology to the production of tissue engineering scaffolds. Euro Cell Mater, 2003, 5: 29-39

61 Liu YJ, Li SJ, Wang HL, et al. Microstructure, defects and mechanical behavior of beta-type titanium porous structures manufactured by electron beam melting and selective laser melting. Acta Mater, 2016, 113: 56-67

62 Murr LE, Quinones SA, Gaytan SM, et al. Microstructure and mechanical behavior of $\mathrm{Ti}-6 \mathrm{Al}-4 \mathrm{~V}$ produced by rapid-layer manufacturing, for biomedical applications. J Mech Behav BioMed Mater, 2009, 2: 20-32

63 Hernandez J, Li SJ, Martinez E, et al. Microstructures and hardness properties for $\beta$-phase $\mathrm{Ti}-24 \mathrm{Nb}-4 \mathrm{Zr}-7.9 \mathrm{Sn}$ alloy fabricated by electron beam melting. J Mater Sci Tech, 2013, 29: 1011-1017

64 Gaytan SM, Murr LE, Martinez E, et al. Comparison of microstructures and mechanical properties for solid and mesh cobaltbase alloy prototypes fabricated by electron beam melting. Metall Mat Trans A, 2010, 41: 3216-3227 
65 Hao YL, Li SJ, Yang R. Biomedical titanium alloys and their additive manufacturing. Rare Met, 2016, 35: 661-671

66 Leukers B, Gülkan H, Irsen SH, et al. Biocompatibility of ceramic scaffolds for bone replacement made by $3 \mathrm{D}$ printing. Mat-wiss $\mathrm{u}$ Werkstofftech, 2005, 36: 781-787

67 Oliveira JM, Rodrigues MT, Silva SS, et al. Novel hydroxyapatite/ chitosan bilayered scaffold for osteochondral tissue-engineering applications: Scaffold design and its performance when seeded with goat bone marrow stromal cells. Biomaterials, 2006, 27: 6123-6137

68 Freed LE, Vunjak-Novakovic G, Biron RJ, et al. Biodegradable polymer scaffolds for tissue engineering. Nat Biotechnol, 1994, 12: $689-693$

69 Hench L, Wilson J. An Introduction to Bioceramics. Singapore: World Scientific, 1993

70 Simske SJ, Ayers RA, Bateman TA. Porous materials for bone engineering. MSF, 1997, 250: 151-182

71 Liulan L, Aili T, Huicun Z, et al. The mechanical properties of bone tissue engineering scaffold fabricating via selective laser sintering. Life System Modeling and Simulation, 2007, 4689: 146152

72 Bignon A, Chouteau J, Chevalier J, et al. Effect of micro- and macroporosity of bone substitutes on their mechanical properties and cellular response. J Mater Sci-Mater Med, 2003, 14: 10891097

73 Chantarapanich N, Puttawibul P, Sucharitpwatskul S, et al. Scaffold library for tissue engineering: a geometric evaluation. Comp Math Methods Med, 2012, 2012: 1-14

74 Richart O, Descamps M, Liebetrau A, et al. Preparation and mechanical characterization of hydroxyapatite monodispersed macroporous structure. Influence of interconnection and macropores diameters. KEM, 2002, 218-220: 9-12

75 Zhao S, Li SJ, Hou WT, et al. The influence of cell morphology on the compressive fatigue behavior of Ti- $6 \mathrm{Al}-4 \mathrm{~V}$ meshes fabricated by electron beam melting. J Mech Behav BioMed Mater, 2016, 59: 251-264

76 Liu YJ, Wang HL, Li SJ, et al. Compressive and fatigue behavior of beta-type titanium porous structures fabricated by electron beam melting. Acta Mater, 2017, 126: 58-66

77 Liu Y, Li S, Hou W, et al. Electron beam melted beta-type Ti$24 \mathrm{Nb}-4 \mathrm{Zr}-8 \mathrm{Sn}$ porous structures with high strength-to-modulus ratio. J Mater Sci Tech, 2016, 32: 505-508

78 Weibmann V, Drescher P, Bader R, et al. Comparison of single Ti6Al4V struts made using selective laser melting and electron beam melting subject to part orientation. Metals, 2017, 7: 91

79 Suard M, Martin G, Lhuissier P, et al. Mechanical equivalent diameter of single struts for the stiffness prediction of lattice structures produced by Electron Beam Melting. Additive Manufacturing, 2015, 8: 124-131

80 Pompe W, Worch H, Epple M, et al. Functionally graded materials for biomedical applications. Mater Sci Eng-A, 2003, 362: 4060

81 Miao X, Sun D. Graded/gradient porous biomaterials. Materials, 2010, 3: 26-47

82 Li S, Zhao S, Hou W, et al. Functionally graded Ti-6Al-4V meshes with high strength and energy absorption. Adv Eng Mater, 2016, 18: $34-38$

83 Hooreweder BV, Lietaert K, Neirinck B, et al. CoCr F75 scaffolds produced by additive manufacturing: Influence of chemical etching on powder removal and mechanical performance. J Mech
Behav BioMed Mater, 2017, 70: 60-67

84 Van Hooreweder B, Apers Y, Lietaert K, et al. Improving the fatigue performance of porous metallic biomaterials produced by selective laser melting. Acta Biomater, 2017, 47: 193-202

85 Liu YJ, Li SJ, Wang HL, et al. Microstructure, defects and mechanical behavior of beta-type titanium porous structures manufactured by electron beam melting and selective laser melting. Acta Mater, 2016, 113: 56-67

86 Pyka G, Burakowski A, Kerckhofs G, et al. Surface modification of Ti6Al4V open porous structures produced by additive manufacturing. Adv Eng Mater, 2012, 14: 363-370

87 Liu X, Chu P, Ding C. Surface modification of titanium, titanium alloys, and related materials for biomedical applications. Mater Sci Eng-R-Rep, 2004, 47: 49-121

88 Mendes VC, Moineddin R, Davies JE. The effect of discrete calcium phosphate nanocrystals on bone-bonding to titanium surfaces. Biomaterials, 2007, 28: 4748-4755

89 Ajami E, Mahno E, Mendes VC, et al. Bone healing and the effect of implant surface topography on osteoconduction in hyperglycemia. Acta Biomater, 2014, 10: 394-405

90 Davies JE, Ajami E, Moineddin R, et al. The roles of different scale ranges of surface implant topography on the stability of the bone/implant interface. Biomaterials, 2013, 34: 3535-3546

91 Nune KC, Misra RDK, Li SJ, et al. The functional response of bioactive titania-modified three-dimensional Ti-6Al-4V mesh structure toward providing a favorable pathway for intercellular communication and osteoincorporation. J Biomed Mater Res, 2016, 104: 2488-2501

92 Nune KC, Misra RDK, Gai X, et al. The role of surface nanotopography on enhanced bioactivity and osteoconductive potential of anodized 3D printed Ti-6Al-4V alloy mesh structure. Coll Surf B: Biointerfaces, 2017. In press

93 Karaji ZG, Hedayati R, Pouran B, et al. Effects of plasma electrolytic oxidation process on the mechanical properties of additively manufactured porous biomaterials. Mat Sci Eng C, 2017, 76: 406-416

94 Amin Yavari S, Ahmadi SM, van der Stok J, et al. Effects of biofunctionalizing surface treatments on the mechanical behavior of open porous titanium biomaterials. J Mech Behav BioMed Mater, 2014, 36: 109-119

95 Nune KC, Misra RDK, Gaytan SM, et al. Biological response of next-generation of 3D Ti-6Al-4V biomedical devices using additive manufacturing of cellular and functional mesh structures. J Biomater Tissue Eng, 2014, 4: 755-771

96 Nune KC, Misra RDK, Gaytan SM, et al. Interplay between cellular activity and three-dimensional scaffold-cell constructs with different foam structure processed by electron beam melting. J Biomed Mater Res, 2015, 103: 1677-1692

97 Oh SH, Park IK, Kim JM, et al. In vitro and in vivo characteristics of PCL scaffolds with pore size gradient fabricated by a centrifugation method. Biomaterials, 2007, 28: 1664-1671

98 Klawitter JJ, Hulbert SF. Application of porous ceramics for the attachment of load bearing internal orthopedic applications. J Biomed Mater Res, 1971, 5: 161-229

99 Griffon DJ, Sedighi MR, Schaeffer DV, et al. Chitosan scaffolds: interconnective pore size and cartilage engineering. Acta Biomater, 2006, 2: 313-320

100 Zardiackas LD, Parsell DE, Dillon LD, et al. Structure, metallurgy, and mechanical properties of a porous tantalum foam. J Biomed Mater Res, 2001, 58: 180-187 
101 Nune KC, Kumar A, Misra RDK, et al. Osteoblast functions in functionally graded Ti-6Al-4 V mesh structures. J Biomater Appl, 2016, 30: 1182-1204

102 Nune KC, Kumar A, Misra RDK, et al. Functional response of osteoblasts in functionally gradient titanium alloy mesh arrays processed by $3 \mathrm{D}$ additive manufacturing. Colloids Surfs BBiointerfaces, 2017, 150: 78-88

103 Ponader S, Vairaktaris E, Heinl P, et al. Effects of topographical surface modifications of electron beam melted Ti-6Al-4V titanium on human fetal osteoblasts. J Biomed Mater Res, 2008, 84A: 1111-1119

104 Rapuano BE, Lee JJE, MacDonald DE. Titanium alloy surface oxide modulates the conformation of adsorbed fibronectin to enhance its binding to $\alpha 5 \beta 1$ integrins in osteoblasts. Eur J Oral Sci, 2012, 120: 185-194

105 Trivedi $\mathrm{P}$, gupta $\mathrm{P}$, Srivastava $\mathrm{S}$, et al. Characterization and in vitro biocompatibility study of $\mathrm{Ti}-\mathrm{Si}-\mathrm{N}$ nanocomposite coatings developed by using physical vapor deposition. Appl Surf Sci, 2014, 293: 143-150

106 Brammer KS, Oh S, Cobb CJ, et al. Improved bone-forming functionality on diameter-controlled $\mathrm{TiO}_{2}$ nanotube surface. Acta Biomater, 2009, 5: 3215-3223

107 Trivedi P, Patel AK, Maurya R, et al. Nanomechanical characterization and protein adsorption of cold-rolled zirconium alloy. JOM, 2015, 67: 726-732

108 Xu JY, Chen XS, Zhang CY, et al. Improved bioactivity of selective laser melting titanium: Surface modification with micro-/ nano-textured hierarchical topography and bone regeneration performance evaluation. Mater Sci Eng-C, 2016, 68: 229-240

109 Tay CY, Irvine SA, Boey FYC, et al. Micro-/nano-engineered cellular responses for soft tissue engineering and biomedical applications. Small, 2011, 7: 1361-1378

110 Gittens RA, McLachlan T, Olivares-Navarrete R, et al. The effects of combined micron-/submicron-scale surface roughness and nanoscale features on cell proliferation and differentiation. Biomaterials, 2011, 32: 3395-3403

111 Zhao L, Mei S, Chu PK, et al. The influence of hierarchical hybrid micro/nano-textured titanium surface with titania nanotubes on osteoblast functions. Biomaterials, 2010, 31: 5072-5082

112 Zhao L, Liu L, Wu Z, et al. Effects of micropitted/nanotubular titania topographies on bone mesenchymal stem cell osteogenic differentiation. Biomaterials, 2012, 33: 2629-2641

113 Kubo K, Tsukimura N, Iwasa F, et al. Cellular behavior on $\mathrm{TiO}_{2}$ nanonodular structures in a micro-to-nanoscale hierarchy model. Biomaterials, 2009, 30: 5319-5329

114 Zhuang XM, Zhou B, Ouyang JL, et al. Enhanced MC3T3-E1 preosteoblast response and bone formation on the addition of nano-needle and nano-porous features to microtopographical titanium surfaces. Biomed Mater, 2014, 9: 045001

115 Wang W, Zhao L, Wu K, et al. The role of integrin-linked kinase/ $\beta$-catenin pathway in the enhanced MG63 differentiation by micro/nano-textured topography. Biomaterials, 2013, 34: 631640

116 Brammer KS, Frandsen CJ, Jin $\mathrm{S}$. $\mathrm{TiO}_{2}$ nanotubes for bone regeneration. Trends Biotech, 2012, 30: 315-322

117 Liu XH, Wu L, Ai HJ, et al. Cytocompatibility and early osseointegration of nanoTiO ${ }_{2}$-modified $\mathrm{Ti}-24 \mathrm{Nb}-4 \mathrm{Zr}-7.9 \mathrm{Sn}$ surfaces. Mater Sci Eng-C, 2015, 48: 256-262

118 Ma XY, Feng YF, Ma ZS, et al. The promotion of osteointegration under diabetic conditions using chitosan/hydroxyapatite com- posite coating on porous titanium surfaces. Biomaterials, 2014, 35: 7259-7270

119 Wang L, Hu X, Ma X, et al. Promotion of osteointegration under diabetic conditions by tantalum coating-based surface modification on 3-dimensional printed porous titanium implants. Colloids Surfs B-Biointerfaces, 2016, 148: 440-452

120 Javed F, Romanos GE. Impact of diabetes mellitus and glycemic control on the osseointegration of dental implants: a systematic literature review. J Periodontology, 2009, 80: 1719-1730

121 Tamam E, Turkyilmaz I. Effects of $\mathrm{pH}$ and elevated glucose levels on the electrochemical behavior of dental implants. J Oral ImPlantology, 2014, 40: 153-159

122 Maló P, de Araújo Nobre M, Gonçalves Y, et al. Long-term outcome of implant rehabilitations in patients with systemic disorders and smoking habits: a retrospective clinical study. Clinical ImPlant Dentistry Related Res, 2016, 18: 649-665

123 Feng YF, Wang L, Zhang Y, et al. Effect of reactive oxygen species overproduction on osteogenesis of porous titanium implant in the present of diabetes mellitus. Biomaterials, 2013, 34: 22342243

124 Trivedi P, Nune KC, Misra RDK. Grain structure dependent selfassembled bioactive coating on $\mathrm{Mg}-2 \mathrm{Zn}-2 \mathrm{Gd}$ alloy: Mechanism of degradation at biointerfaces. Surf Coatings Tech, 2017, 315: 250257

125 Morscher EW, Hefti A, Aebi U. Severe osteolysis after third-body wear due to hydroxyapatite particles from acetabular cup coating. J Bone Joint Surgery, 1998, 80: 267-272

126 Røkkum M, Reigstad A, Johansson CB. HA particles can be released from well-fixed HA-coated stems. Acta Orthopaedica Scandinavica, 2002, 73: 298-306

127 Nune KC, Kumar A, Murr LE, et al. Interplay between self-assembled structure of bone morphogenetic protein-2 (BMP-2) and osteoblast functions in three-dimensional titanium alloy scaffolds: Stimulation of osteogenic activity. J Biomed Mater Res, 2016, 104: 517-532

128 Kumar A, Nune KC, Misra RDK. Biological functionality and mechanistic contribution of extracellular matrix-ornamented three dimensional Ti-6Al-4V mesh scaffolds. J Biomed Mater Res, 2016, 104: 2751-2763

129 Liu H, Li W, Liu C, et al. Incorporating simvastatin/poloxamer 407 hydrogel into 3D-printed porous $\mathrm{Ti}_{6} \mathrm{Al}_{4} \mathrm{~V}$ scaffolds for the promotion of angiogenesis, osseointegration and bone ingrowth. Biofabrication, 2016, 8: 045012

130 Murr LE, Gaytan SM, Medina F, et al. Next-generation biomedical implants using additive manufacturing of complex, cellular and functional mesh arrays. Philos Trans R Soc A-Math Phys Eng Sci, 2010, 368: 1999-2032

131 Torres J, Tamimi F, Alkhraisat MH, et al. Vertical bone augmentation with 3D-synthetic monetite blocks in the rabbit calvaria. J Clin Periodontol, 2011, 38: 1147-1153

132 Wu BM, Borland SW, Giordano RA, et al. Solid free-form fabrication of drug delivery devices. J Control Release, 1996, 40: 7787

133 Katstra WE, Palazzolo RD, Rowe CW, et al. Oral dosage forms fabricated by Three Dimensional Printing ${ }^{\mathrm{TM}}$. J Control Release, 2000, 66: 1-9

$134 \mathrm{Wu}$ W, Zheng Q, Guo X, et al. The controlled-releasing drug implant based on the three dimensional printing technology: Fabrication and properties of drug releasing in vivo. J Wuhan Univ Technol-Mat Sci Edit, 2009, 24: 977-981 
135 Yu DG, Zhu LM, Branford-White CJ, et al. Three-dimensional printing in pharmaceutics: promises and problems. J Pharmaceutical Sci, 2008, 97: 3666-3690

136 Kuboki Y, Jin Q, Takita H. Geometry of carriers controlling phenotypic expression in BMP-induced osteogenesis and chondrogenesis. J Bone Joint Surg, 2001, 83: S105-S115

137 Tsuruga E, Takita $\mathrm{H}$, Itoh $\mathrm{H}$, et al. Pore size of porous hydroxyapatite as the cell-substratum controls BMP-induced osteogenesis. J Biochem, 1997, 121: 317-324

138 Yarlagadda P, Chandrasekharan M, Shyan J. Recent advances and current developments in tissue scaffolding. Biomed Mater Eng, 2005, 15: 159-177

139 Carmeliet P. Mechanisms of angiogenesis and arteriogenesis.. Nat Med, 2000, 6: 389-395

140 Laschke MW, Harder Y, Amon M, et al. Angiogenesis in tissue engineering: breathing life into constructed tissue substitutes. Tissue Eng, 2006, 12: 2093-2104

141 Rouwkema J, Rivron NC, van Blitterswijk CA. Vascularization in tissue engineering. Trends Biotech, 2008, 26: 434-441

142 Malda J, Rouwkema J, Martens DE, et al. Oxygen gradients in tissue-engineered Pegt/Pbt cartilaginous constructs: Measurement and modeling. Biotechnol Bioeng, 2004, 86: 9-18

143 Folkman J. Self-regulation of growth in three dimensions. J Exp Med, 1973, 138: 745-753

144 Colton CK. Implantable biohybrid artificial organs. Cell TransPlantation, 1995, 4: 415-436

145 Carmeliet P, Jain RK. Angiogenesis in cancer and other diseases.. Nature, 2000, 407: 249-257

146 Kannan RY, Salacinski HJ, Sales K, et al. The roles of tissue engineering and vascularisation in the development of microvascular networks: a review. Biomaterials, 2005, 26: 1857-1875

147 Druecke D, Langer S, Lamme E, et al. Neovascularization of poly (ether ester) block-copolymer scaffolds in vivo: long-term investigations using intravital fluorescent microscopy. J Biomed Mater Res, 2004, 68A: 10-18

148 Hutmacher DW, Sittinger M, Risbud MV. Scaffold-based tissue engineering: rationale for computer-aided design and solid freeform fabrication systems. Trends Biotech, 2004, 22: 354-362

149 Novosel EC, Kleinhans C, Kluger PJ. Vascularization is the key challenge in tissue engineering. Adv Drug Deliver Rev, 2011, 63: 300-311

150 Liu WF, Chen CS. Engineering biomaterials to control cell function. Mater Today, 2005, 8: 28-35

151 Hutmacher DW. Scaffold design and fabrication technologies for engineering tissues-state of the art and future perspectives. J BioMater Sci Polymer Ed, 2001, 12: 107-124

152 Anderson CR, Ponce AM, Price RJ. Immunohistochemical identification of an extracellular matrix scaffold that microguides capillary sprouting in vivo. J Histochem Cytochem, 2004, 52: 1063-1072

153 Ochman S, Frey S, Raschke MJ, et al. Local application of VEGF compensates callus deficiency after acute soft tissue trauma-results using a limb-shortening distraction procedure in rabbit tibia. J Orthop Res, 2011, 29: 1093-1098

154 Trueta J, Little K. The vascular contribution to osteogenesis II. Studies with the electron microscope. J Bone Joint Surg Br, 1960, 42-B: $367-376$

155 Bose S, Roy M, Bandyopadhyay A. Recent advances in bone tissue engineering scaffolds. Trends Biotech, 2012, 30: 546-554

156 Holder Jr. WD, Gruber HE, Roland WD, et al. Increased vascu- larization and heterogeneity of vascular structures occurring in polyglycolide matrices containing aortic endothelial cells implanted in the rat. Tissue Eng, 1997, 3: 149-160

157 Mooney DJ, Mikos AG. Growing new organs. Sci Am, 1999, 280: 60-65

158 Muller D, Chim H, Bader A, et al. Vascular guidance: microstructural scaffold patterning for inductive neovascularization. Stem Cells Int, 2011, 2011: 1-6

159 Prasad K, Bazaka O, Chua M, et al. Metallic biomaterials: current challenges and opportunities. Materials, 2017, 10: 884-917

160 Li S, Li X, Hou W, et al. Fabrication of open-cellular (porous) titanium alloy implants: osseointegration, vascularization and preliminary human trials. Sci China Mater, 2018, 61: 525-536

161 Fan H, Fu J, Li X, et al. Implantation of customized 3-D printed titanium prosthesis in limb salvage surgery: a case series and review of the literature. World J Surg Onc, 2015, 13: 308-317

162 Ponader S, von Wilmowsky C, Widenmayer $\mathrm{M}$, et al. In vivo performance of selective electron beam-melted Ti-6Al-4V structures. J Biomed Mater Res, 2010, 92A: 56-62

163 Hollander DA, von Walter M, Wirtz T, et al. Structural, mechanical and in vitro characterization of individually structured Ti-6Al-4V produced by direct laser forming. Biomaterials, 2006, 27: 955-963

164 Van Bael S, Chai YC, Truscello S, et al. The effect of pore geometry on the in vitro biological behavior of human periosteumderived cells seeded on selective laser-melted Ti6Al4V bone scaffolds. Acta Biomater, 2012, 8: 2824-2834

165 Butscher A, Bohner M, Hofmann S, et al. Structural and material approaches to bone tissue engineering in powder-based threedimensional printing. Acta Biomater, 2011, 7: 907-920

166 Sobral JM, Caridade SG, Sousa RA, et al. Three-dimensional plotted scaffolds with controlled pore size gradients: effect of scaffold geometry on mechanical performance and cell seeding efficiency. Acta Biomater, 2011, 7: 1009-1018

167 Olivares-Navarrete R, Gittens RA, Schneider JM, et al. Osteoblasts exhibit a more differentiated phenotype and increased bone morphogenetic protein production on titanium alloy substrates than on poly-ether-ether-ketone. Spine J, 2012, 12: 265-272

168 Levchenko I, Ostrikov KK, Zheng J, et al. Scalable graphene production: perspectives and challenges of plasma applications. Nanoscale, 2016, 8: 10511-10527

169 Lethaus B, Kessler P, Boeckman R, et al. Reconstruction of a maxillary defect with a fibula graft and titanium mesh using CAD/CAM techniques. Head Face Med, 2010, 6: 16-19

170 Malhotra K, Sharma A, Giraddi G, et al. Versatility of titanium 3D plate in comparison with conventional titanium miniplate fixation for the management of mandibular fracture. J Maxillofac Oral Surg, 2012, 11: 284-290

171 Lee UL, Kwon JS, Woo SH, et al. Simultaneous bimaxillary surgery and mandibular reconstruction with a 3-dimensional printed titanium implant fabricated by electron beam melting: A preliminary mechanical testing of the printed mandible. J Oral Maxillofac Surg, 2016, 74: 1501

Acknowledgements Nune KC and Misra RDK acknowledge support from the Department of Metallurgical, Materials and Biomedical Engineering, University of Texas at El Paso. All the authors acknowledge different reference sources that enabled the authors to prepare this overview article. The authors have done their best in citing all the relevant articles, however, inadvertently there may be situations where an 
article has not been appropriately cited. All figures adapted from different references and reference number is indicated in the figure caption. Li S greatly acknowledges support of the Key Research Program of Frontier Science, CAS (QYZDJ-SSW-JSC031-02)
Author contributions Nune KC and Misra RDK wrote the paper and Li S contributed to the discussion.

Conflict of interest The authors declare that they have no conflict of interest.

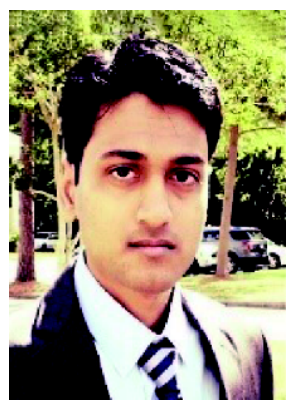

Krishna Chaitanya Nune is a senior research scientist in the Department of Metallurgical, Materials and Biomedical Engineering, University of Texas at El Paso, USA. His research interests are in biomaterials.
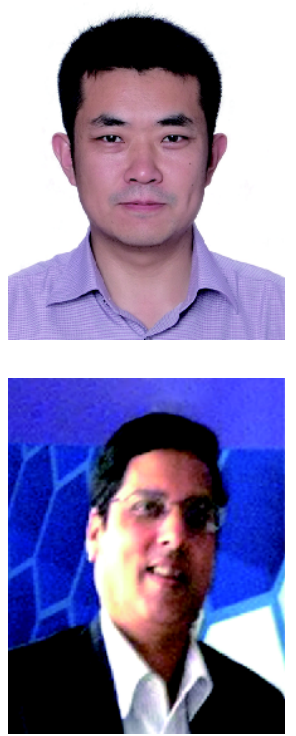

Shujun Li is a tenured professor in Shenyang National Laboratory for Materials Science, Institute of Metal Research, Chinese Academy of Sciences. His current research interest focuses on additive manufacturing via electron beam melting technology, aiming to understand the structure-process-property relationship of 3D printable metallic materials and explore their practical applications in aerospace and biomedical components, etc.
R. Devesh Kumar Misra is a professor and Chair of the Department of Metallurgical, Materials and Biomedical Engineering, University of Texas at El Paso, USA. The research interests are in biomaterials, nanostructured materials, deformation and fracture, and additive manufacturing.

\section{电子束增材制造医用针合金三维多孔支架力学及生物功能研究进展}

Krishna Chaitanya Nune ${ }^{1}$, 李述军 ${ }^{2}$, R. Devesh Kumar Misra ${ }^{1^{*}}$

摘要 本文综述了电子束增材制造法(EBM)制备医用钛合金多孔支架植入物的工艺-结构-性能之间关系. 传统加工多孔材料方法(如冷冻 铸造及烧结法)制备的多孔植入器械由于很难匹配患病部位以及与人体组织在宏微观结构、力学和物理性能存在差异等因素受到很多限 制. 针对这一问题, EBM方法具有独特的优势. 它可以利用患病部位的CT扫描成像或者CAD程序设计制备出复杂个性化多孔植入器械. 本 文概述了用于组织再生 $3 \mathrm{D}$ 打印多孔支架的发展历程, 主要包含两部分: 第一部分介绍了EBM法制备的具有不同特征(设计、结构单元、加 工参数、扫描速率、孔隙率及热处理)钛合金多孔支架的力学性能; 第二部分介绍了多孔支架生物响应的改进优化以及表面改性对细胞材料交互作用的研究进展. 最后, 本文还讨论了三维多孔钛合金支架的临床试验结果, 并展望了其在生物医疗领域的应用前景. 